\title{
High value-added products derived from crude glycerol via microbial fermentation using Yarrowia clade yeast
}

\author{
Magdalena Rakicka-Pustułka ${ }^{*}$ (D), Joanna Miedzianka², Dominika Jama', Sylwia Kawalec ${ }^{1}$, Kamila Liman', \\ Tomasz Janek', Grzegorz Skaradziński', Waldemar Rymowicz' and Zbigniew Lazar ${ }^{1}$
}

\begin{abstract}
Background: Contemporary biotechnology focuses on many problems related to the functioning of developed societies. Many of these problems are related to health, especially with the rapidly rising numbers of people suffering from civilization diseases, such as obesity or diabetes. One factor contributing to the development of these diseases is the high consumption of sucrose. A very promising substitute for this sugar has emerged: the polyhydroxy alcohols, characterized by low caloric value and sufficient sweetness to replace table sugar in food production.

Results: In the current study, yeast belonging to the Yarrowia clade were tested for erythritol, mannitol and arabitol production using crude glycerol from the biodiesel and soap industries as carbon sources. Out of the 13 tested species, Yarrowia divulgata and Candida oslonensis turned out to be particularly efficient polyol producers. Both species produced large amounts of these compounds from both soap-derived glycerol (59.8-62.7 g dm${ }^{-3}$ ) and biodieselderived glycerol $\left(76.8-79.5 \mathrm{~g} \mathrm{dm}^{-3}\right)$. However, it is equally important that the protein and lipid content of the biomass (around 30\% protein and 12\% lipid) obtained after the processes is high enough to use this yeast in the production of animal feed.
\end{abstract}

Conclusions: The use of waste glycerol for the production of polyols as well as utilization of the biomass obtained after the process for the production of feed are part of the development of modern waste-free technologies.

Keywords: Yarrowia clade, Crude glycerol, Polyols, Single cell protein, Single cell oil

\section{Background}

The Yarrowia clade is a group of yeasts consisting of Candida alimentaria, Candida bentonensis, Candida hispaniensis, Candida pseudorhagii, Yarrowia brassicae, Yarrowia bubula, Yarrowia deformans, Yarrowia divulgata, Candida galli, Candida hollandica, Yarrowia lipolytica, Candida oslonensis, Yarrowia paraphonii, Yarrowia phangngaensis, Yarrowia porcina, Yarrowia

\footnotetext{
*Correspondence: magdalena.rakicka-pustulka@upwr.edu.pl

${ }^{1}$ Department of Biotechnology and Food Microbiology, Wroclaw

University of Environmental and Life Sciences, Chełmońskiego 37, 51-630 Wroclaw, Poland

Full list of author information is available at the end of the article
}

yakushimensis, and Yarrowia keelungensis, isolated from different biotic and abiotic environments, e.g. food, sea water, termite intestine [26, 36]. This group of microorganisms is very diverse, and still little is known about their detailed physiology and even less about their full biotechnological potential. Enormous physiological and metabolic diversity exists among the clade members, not only with respect to the different carbon sources used by these species, different growth rates and nutritional requirements, but also differences in protein families (lipases) as well as in protein structure, especially the very important hexokinase responsible for sugar metabolism $[12,34,45,48]$. Nonetheless, from the biotechnological point of view, the most important difference is in the original author(s) and the source, provide a link to the Creative Commons licence, and indicate if changes were made. The images or other third party material in this article are included in the article's Creative Commons licence, unless indicated otherwise in a credit line to the material. If material is not included in the article's Creative Commons licence and your intended use is not permitted by statutory regulation or exceeds the permitted use, you will need to obtain permission directly from the copyright holder. To view a copy of this licence, visit http://creativecommons.org/licenses/by/4.0/. The Creative Commons Public Domain Dedication waiver (http://creativeco mmons.org/publicdomain/zero/1.0/) applies to the data made available in this article, unless otherwise stated in a credit line to the data. 
enormous amount of the metabolite produced by these yeasts [45, 48]. Until now, assimilation of different carbon sources (sugars, free fatty acids, triacylglycerols) and production of lipids by Yarrowia clade members have been investigated [34, 36]. The potential of lipid production was further evaluated using cheap substrates such as nondetoxified dilute acid-pretreated switchgrass hydrolysate under highly aerobic conditions [45]. Furthermore, an extensive analysis of production of polyols (mannitol, arabitol, erythritol) and citric acid by the different Yarrowia clade species growing in medium containing pure glycerol, fructose and glucose was performed [48]. Very recently, Morin et al. [37] reported the first genetic modification of Candida hispaniensis related to the introduction of a heterologous invertase allowing growth on sucrose using a biolistic transformation approach and a dedicated vector.

Single cell protein (SCP), biomass derived from yeast, bacteria, fungi or algae, can be used as a source of protein, mineral elements and vitamins in animal and human nutrition [58]. The proteins from yeast, being the most accepted by consumers, is rich in lysine, leucine, threonine, and valine, as well as including small amounts of cysteine and methionine [19]. The important advantage of SCP production using yeast is not only the utilization of waste or byproducts from other industries but also simultaneous production of high value-added compounds [8]. Apart from potential biosynthesis of SCP, also single cell oil (SCO) can be produced. The SCO, intracellular storage lipids, occurs mostly in the form of triacylglycerols and steryl esters. Yeast can accumulate 20\% to $80 \%$ of lipids inside the cell under nutrient-limiting conditions (nitrogen or phosphorus) with simultaneous excess of carbon source $[9,28]$. Certainly, the development of SCO production technology is also dictated by the controversial discussion over "food or fuel" associated with the utilization of plant oils as substrates for biodiesel production [39]. No less an important aspect related to the use of yeast from the Yarrowia clade is their ability to synthesize polyhydroxyalcohols. In recent years, extensive studies have been dedicated to developing biotechnological production of these valuable compounds by Y. lipolytica [4, 11, 33, 49, 53]. Replacing sugars with polyols is not an easy task, especially due to the economic aspects. Therefore, searching for new microorganisms and improvement of existing polyol biosynthesis methods lowering the production costs are of high interest.

Every biotechnological process, especially contributing to the circular economy, requires application of cheap and renewable carbon source. One biodegradable industrial feedstock, nowadays frequently applied as a substrate for microorganisms, is crude glycerol generated during biodiesel or soap production (Fig. 1).
During 1 ton of biodiesel production up to $100 \mathrm{~kg}$ of crude glycerol is generated [16]. To be able to use it in the food, chemicals and cosmetics industries [53], it is necessary to apply expensive purification processes. Crude glycerol instead, due to its large amount of impurities, has limited direct applications (Fig. 1). These limitations were overcome by utilization of raw glycerol as a substrate for microbial fermentation to produce organic solvents, polyhydroxyalkanoates, organic acids as well as polyols (Fig. 1; [53]). Currently, the rapid annual growth of biodiesel production generates large amounts of crude glycerol, also rapidly increasing. For this reason, it has become very important to find an alternative method of its utilization, as the current supply of pure glycerol is sufficient for the industries using it [16]. Development of crude glycerol based processes will also greatly contribute to the undisturbed development of the biodiesel industry [58]. Hence, identification of new microorganisms efficiently using raw glycerol and synthesizing large amounts of value-added chemicals is crucial for developing profitable processes well suited to the circular economy.

In the current study, we investigated the abilities of Yarrowia clade yeasts to use raw glycerol derived from the soap and biodiesel industries for biosynthesis of mannitol, arabitol and erythritol. Furthermore, lipid and protein content as well as amino acid composition of the yeast biomass was also evaluated, which shows the great potential of using waste biomass as an ingredient for the production of animal feed. The presented technology shows great potential of Yarrowia clade members to recycle waste compounds, reduce their negative environmental impact, and to reduce the overall costs associated with waste management.

\section{Results and discussion}

As mentioned in the introduction, the capacity of the Yarrowia clade yeasts for polyhydroxyalcohol production has already been analyzed [48]. In that study, however, pure substrates were used as carbon sources (glucose, fructose and glycerol). As expected, similarly to $Y$. lipolytica, other clade members produced polyols mainly using glycerol, whereas sugars were not a good substrate for biosynthesis of sweeteners. It is mainly related to the osmotic pressure caused by glycerol. Although polyol biosynthesis by Yarrowia clade members was analyzed using pure glycerol, to fulfill the expectations of the circular economy and develop sustainable processes, in the current study crude glycerol, a waste product from two industries, the production of biodiesel and the production of soap, was investigated. 


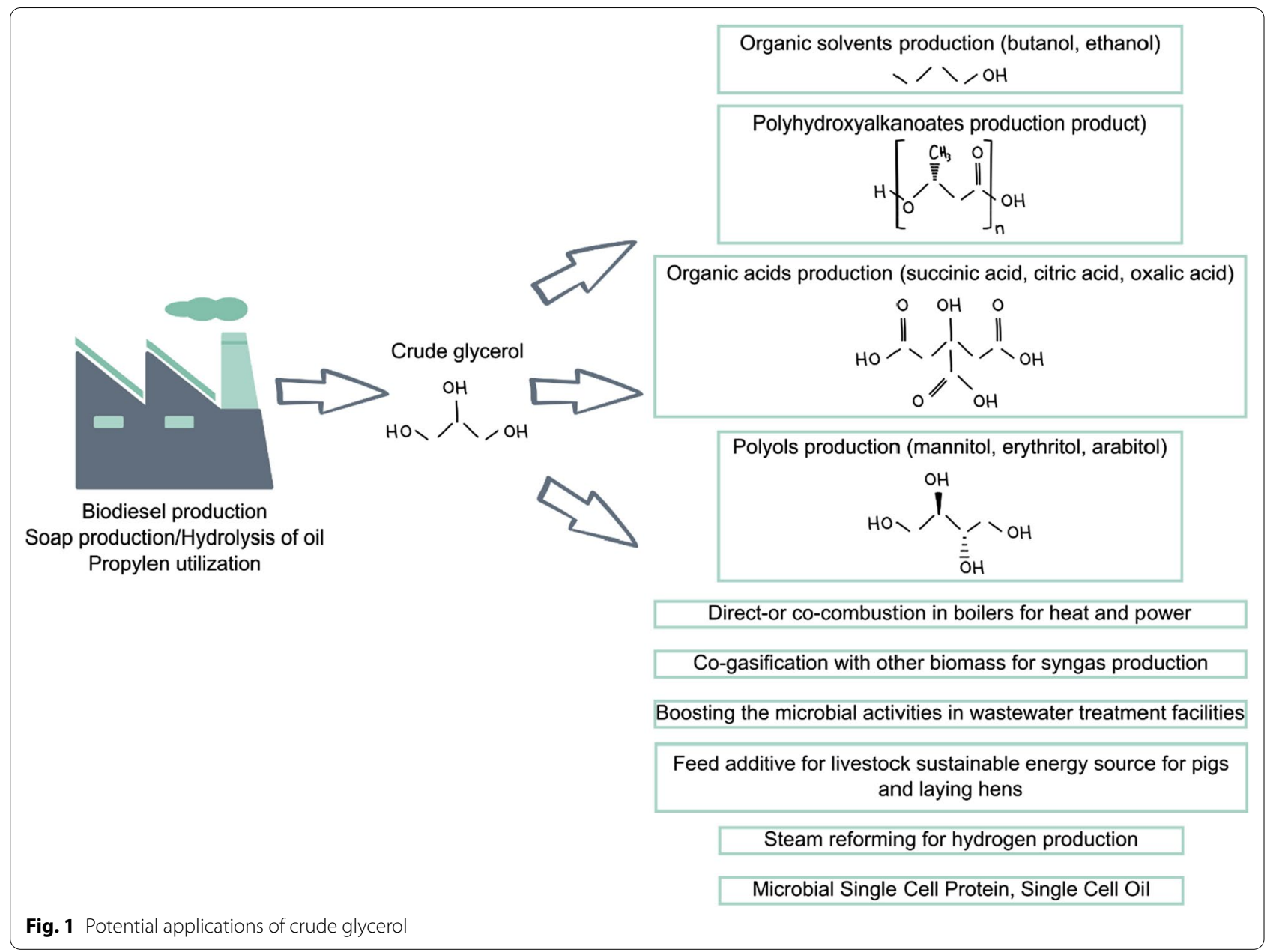

\section{Growth of Yarrowia clade on crude glycerol}

First, the ability of different Yarrowia clade species to grow in a medium with different sources of waste glycerol was investigated. The characteristics of the different carbon sources are presented in Table 1. In the reference experiment, all the strains were cultured in medium with pure glycerol (Fig. 2a). In this control experiment, no growth inhibitors, such as salts or heavy metals, were present in the medium. Furthermore, the most studied yeast, $Y$. lipolytica, known to grow well on glycerol, was used as a reference species here and throughout the entire study. Some differences in the growth profiles of the different species could be observed. The slowest performing species or species with a long lag phase were found to be YAYA and YAAL, but the final $\mathrm{OD}_{600}$ of these yeasts was similar to other clade members (Fig. 2a).

Similarly to the medium with pure glycerol, also in YNB medium based on crude glycerol from the biodiesel industry, YAYA and YAAL showed slow or delayed growth (Fig. 2b). Surprisingly, also A101 grew significantly slower than other clade members, which was not as clearly observed in pure glycerol (Fig. 2b). The largest differences, mostly in growth curves of the Yarrowia clade members, were observed when crude glycerol from the soap industry was used as a carbon source (Fig. 2c). This substrate was highly polluted by salt and MONG (matter organic nonglycerol) (Table 1). However, the contaminations present in this crude glycerol did not weaken the growth of yeast cells. Unlike previous cultures, two strains exhibited very different growth profiles than other species, YAPO and YAHO (Fig. 2c), and reached the highest final $O_{600}$ among the tested clade members. Once again, YAYA and YAAL exhibited long or delayed growth. Furthermore, this substrate caused a diauxic growth profile for some of the species (YADE, YAHO, YAPH, also the slowly growing YAAL). Moreover, OLHI was one of the species which grew very well in medium with every analyzed glycerol. 
Table 1 Characteristics of glycerol used in this study

\begin{tabular}{|c|c|c|c|}
\hline Name & GLY 1 & GLY 2 & GLY 3 \\
\hline Company & Poch, Gliwice, Poland & ORLEN Południe, Trzebinia, Poland & Grupa Azoty, Chorzów, Poland \\
\hline Origin & $\begin{array}{l}\text { Waste from biodiesel } \\
\text { production }\end{array}$ & Waste from biodiesel production & Waste from soap production \\
\hline Purity (\%) & 98 & 87 & 80 \\
\hline Water \% (m/m) & 0.5 & 15 & 3.6 \\
\hline Methanol \% (m/m) & 0 & 0.3 & 0.2 \\
\hline $\begin{array}{l}\text { MONG (matter organic non glycerol) } \\
\%(\mathrm{~m} / \mathrm{m})\end{array}$ & 0 & 6 & 4.0 \\
\hline $\mathrm{NaCl} \%(\mathrm{~m} / \mathrm{m})$ & 0 & 0 & 7.59 \\
\hline Methanol \% (m/m) & 0 & 0.3 & 0.2 \\
\hline Nitrogen content & 0 & 0.023 & 0.041 \\
\hline Ash & 0 & 0.93 & 8.76 \\
\hline $\mathrm{Cu}(\mathrm{mg} / \mathrm{kg})$ & 0 & 0.096 & 0.66 \\
\hline $\mathrm{Mg}(\mathrm{mg} / \mathrm{kg})$ & 0 & 1.68 & 5.45 \\
\hline $\mathrm{Fe}(\mathrm{mg} / \mathrm{kg})$ & 0 & 1.99 & 26.42 \\
\hline Zn (mg/kg) & 0 & 0.09 & 1.30 \\
\hline $\mathrm{K}(\mathrm{mg} / \mathrm{kg})$ & 0 & 4388.16 & 231.32 \\
\hline $\mathrm{Na}(\mathrm{mg} / \mathrm{kg})$ & 0 & 422.85 & $31,632.89$ \\
\hline $\mathrm{Cl}(\mathrm{mg} / \mathrm{kg})$ & 0 & 1200 & 46,000 \\
\hline $\mathrm{Ca}(\mathrm{mg} / \mathrm{kg})$ & 0 & 40.27 & 52.36 \\
\hline
\end{tabular}

\section{Polyol synthesis by Yarrowia clade yeast during the shake-flask experiment}

In the next step, biosynthesis of polyols was analyzed in shake flask cultures using crude glycerol. Pure substrate of technical grade was used in a control experiment. Very high diversity could be observed among the Yarrowia clade members depending on the substrate used (Fig. 3). Interestingly, the yields of erythritol and arabitol (both from the biomass and from the substrate) were higher than the same parameters obtained for mannitol (Fig. 3a, b). Until now, the best known species belonging to the Yarrowia clade, Y. lipolytica, is known to produce mostly erythritol and mannitol [47, 60]. The highest erythritol yield from biomass was noted for YALI, YABU, YAPO, YAYA (Fig. 3a), whereas the highest erythritol yield from pure glycerol was observed for different species, YAAL, YAKE, YAHO and YAOS and ranged from 0.35 to $0.41 \mathrm{~g} \mathrm{~g}^{-1}$ (Fig. 3b). In turn, the best arabitol producers were YAYA, YAPO and YADI strains, for which the yield from biomass was higher than $3.0 \mathrm{~g} \mathrm{~g}^{-1}$ (Fig. 3a). The highest arabitol yield from pure glycerol was observed for YAYA $\left(0.28 \mathrm{~g} \mathrm{~g}^{-1}\right)$. Mannitol production was significant only for the OLHI strain, where the yield from glycerol reached $0.2 \mathrm{~g} \mathrm{~g}^{-1}$ (Fig. 3b). It should be pointed out here that in the analyzed conditions, for YADE, YADI, YAGA, YAPH and OLHI the product yield from the consumed substrate for arabitol was the highest among the three polyols. This phenomenon was observed for the first time and suggests different kinetic characteristics of the enzymes from the pentose phosphate pathway among clade members.

Very interesting results for the analyzed species were obtained when pure glycerol was substituted by the crude one. Using raw glycerol from the biodiesel industry, the polyol ratio changed (Fig. 3c, d). YADI, YAGA, YAPO and YAYA were characterized by a clear predominance of erythritol biosynthesis (Fig. 3d) compared to the medium with pure glycerol (Fig. 3b). Furthermore, seven strains produced more than $0.4 \mathrm{~g} \mathrm{~g}^{-1}$ of erythritol (Fig. 3d), which was the highest value when pure glycerol was used as a substrate (Fig. 3b). It was interesting that YABU significantly increased the biosynthesis of arabitol, while OLHI was again the only species with a significant amount of mannitol synthesized (Fig. 3d). Moreover, the amount of polyols produced from the biomass reached much higher values when crude glycerol from the biodiesel industry was used (Fig. 3c). Yield much higher than the one obtained for YALI (Y. lipolytica, a control species) were observed for YABU, YADI, YAOS, YAYA, while YABU also produced the highest amount of arabitol at the same time (Fig. 3c). The obtained data confirmed that polyol biosynthesis strongly depends on the composition of the medium, which in our study was strongly connected to the components in raw glycerol.

Lower polyol biosynthesis was observed when crude glycerol from soap production was used as a 

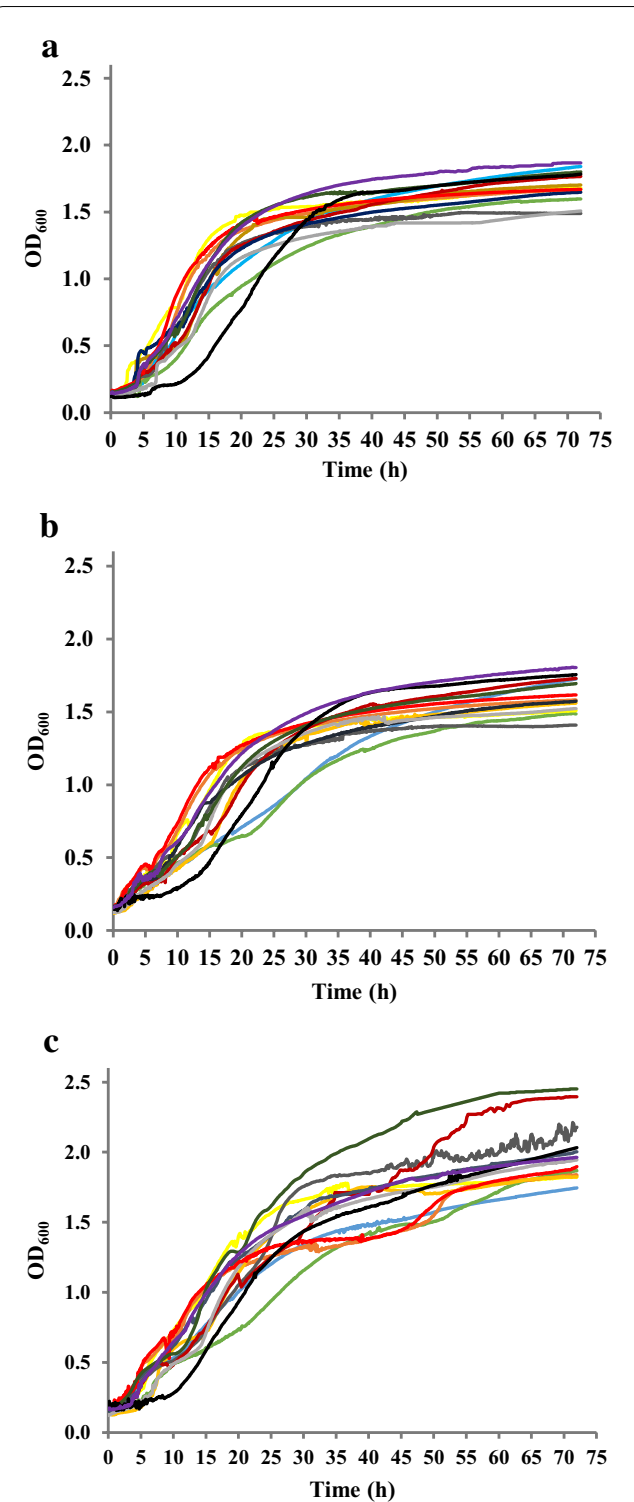

Fig. 2 Growth curves of Yarrowia clade yeast growing on: a pure glycerol, $\mathbf{b}$ crude glycerol from biodiesel industry or c crude glycerol from soap production. Triple experiments were performed at $28^{\circ} \mathrm{C}$ under constant agitation using microplate reader

carbon source (Fig. 3e, f). Only three species produced more than $0.5 \mathrm{~g} \mathrm{~g}^{-1}$ of erythritol-YAAL, YAGA, YAOS (Fig. 3f). Two species significantly changed their profile of polyols secreted. Of these, raw glycerol YABU produced much more erythritol than arabitol (ARA:ERY $=0.62$ for glycerol from the soap industry, whereas ARA:ERY $=1.67$ was observed from glycerol obtained from the biodiesel industry). The opposite situation was noted for YAYA, which secreted more arabitol than erythritol (ARA:ERY $=1.32$ for soap derived glycerol and ARA:ERY $=0.48$ for biodiesel derived glycerol). Furthermore, three species (YADI, YAGA, OLHI) secreted mannitol in a significant amount as its yield exceeded $0.2 \mathrm{~g} \mathrm{~g}^{-1}$. Taking into account the yield of erythritol from biomass, four species deserve attentionYALI, YAAL, YAGA, YAOS - whereas considering arabitol yield from biomass YAYA stands out clearly (Fig. 3e). The different production of polyols in the medium with crude glycerol from the soap industry compared to the biodiesel-derived glycerol is very likely caused by the presence of sodium chloride in the former. For Y. lipol$y$ tica, the optimal concentration of sodium chloride to induce appropriate osmotic pressure for erythritol biosynthesis is $2.5 \%$ [60]. However, in the current study, a similar concentration of total polyols was observed for YALI when both crude glycerols were applied as carbon sources $\left(Y_{\mathrm{P} / \mathrm{S}}=0.78 \mathrm{~g} \mathrm{~g}^{-1}\right.$ for biodiesel derived glycerol and $0.72 \mathrm{~g} \mathrm{~g}^{-1}$ for soap derived glycerol; Fig. 3d, f). In contrast, lower amounts of these compounds were obtained from pure glycerol $\left(\mathrm{Y}_{\mathrm{P} / \mathrm{S}}=0.52 \mathrm{~g} \mathrm{~g}^{-1}\right.$, Fig. $\left.3 \mathrm{~b}\right)$. This difference is probably due to the presence of additional components present in crude glycerol (see "Methods"). It is worth pointing out that no organic acids were produced during the shake flask cultures.

Summarizing the observations, the species belonging to Yarrowia clade proved to have promising potential for efficient polyol biosynthesis using crude glycerol as a carbon source. Comparing the present results to data available in the literature, erythritol yield obtained for YAHO and YAAL $\left(0.57 \mathrm{~g} \mathrm{~g}^{-1}\right)$ is quite high and was not observed previously for any known species during flask cultures. The well-characterized species $Y$. lipolytica, when cultivated in flask cultures, secreted $20-35 \mathrm{~g} \mathrm{dm}^{-3}$ of erythritol with a yield ranging from 0.33 to $0.42 \mathrm{~g} \mathrm{~g}^{-1}$ [60]. The best yield obtained in a flask scale experiment reported $0.52 \mathrm{~g} \mathrm{~g}^{-1}$ of erythritol for Y. lipolytica strain ACA-YC 5030 [42]. A similar type of culture for Candida magnoliae allowed only $0.08 \mathrm{~g} \mathrm{~g}^{-1}$ of this valuable compound to be obtained [21]. A very valuable result obtained in this study was the large amount of arabitol produced by clade members, especially YABU, YAPH and YAYA. It is the first report of Yarrowia yeast secreting this polyol in this amount; however, to further improve it, optimization of media components and culture parameters is needed. So far, strains of Debaryomyces hansenii have been among the best arabitol producers, especially SBP-1 (NRRL Y-7483), reaching $0.5 \mathrm{~g} \mathrm{~g}^{-1}$ with initial glycerol concentration of $150 \mathrm{~g} \mathrm{dm}^{-3}$ [23].

\section{Polyols as value-added chemicals synthesized from crude glycerol by Yarrowia clade on bioreactor scale}

In the next step of the research, all strains belonging to the Yarrowia clade were analyzed for polyol secretion on 

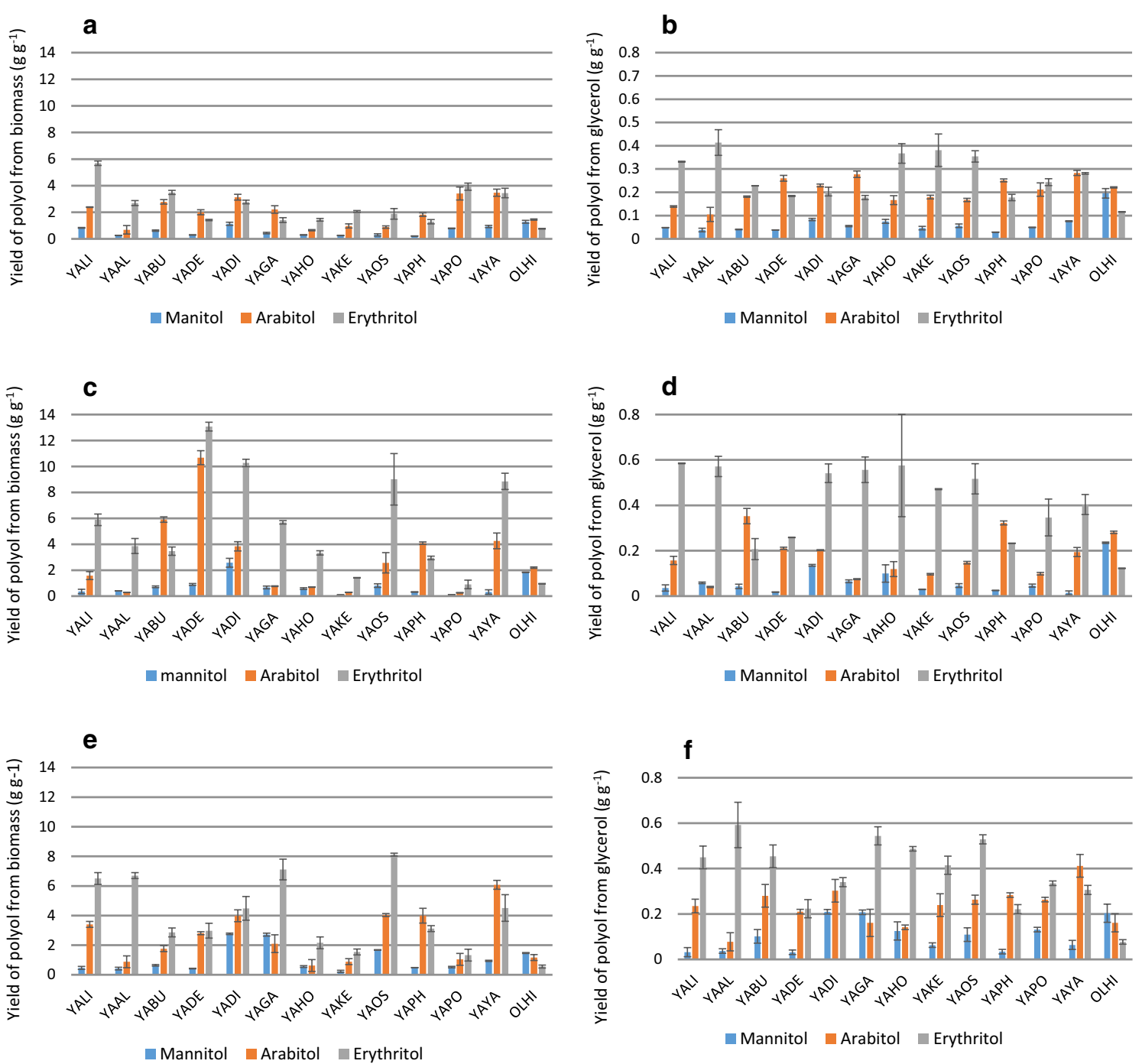

Fig. 3 Yield of polyol production from: a, b biomass growing on pure glycerol, $\mathbf{c}, \mathbf{d}$ crude glycerol from biodiesel industry and $\mathbf{e}$, $\mathbf{f}$ crude glycerol from soap production by yeast belonging to Yarrowia clade during shake-flask experiment

a larger scale. Cultures were performed in $5 \mathrm{dm}^{3}$ bioreactors in a working volume of $2 \mathrm{dm}^{3}$. Two glycerol types were used-technical as well as glycerol from biodiesel production. Figure 4 represents the main parameters characterizing the performed cultures of all analyzed species growing in medium with either pure or crude glycerol. Not only were differences among all analyzed species observed but also very large differences were noted when the same species was growing in pure or crude glycerol. The cultures on pure glycerol lasted from $54 \mathrm{~h}$ for YAGA and YADI to $168 \mathrm{~h}$ for OLHI strains (Fig. 4). The duration of cultures using crude substrate in many cases was extended. The only species requiring $72 \mathrm{~h}$ to consume all available glycerol when growing in crude glycerol based medium was YAPO. The highest concentration of biomass (approximately $30 \mathrm{~g} \mathrm{dm}^{-3}$ ) was achieved by YAPH and YADE growing in pure glycerol, whereas YADE reached $34.2 \mathrm{~g} \mathrm{dm}^{-3}$ when growing in crude glycerol (Fig. 4). YAGA turned out to be the species growing the worst when crude glycerol from the biodiesel industry was used as a carbon source (Fig. 4). This species also showed the worst growth in our previous studies in medium containing $\mathrm{NaCl}$ [48]. It is sensitive to $\mathrm{NaCl}$ and/or other mineral salts which might be present in the crude glycerol.

All parameters characterizing bioreactor cultures with pure and crude glycerol from the biodiesel industry are summarized in Fig. 5 and Additional file 1: Table S1. The best producers of polyols from crude glycerol, where the sum of mannitol, arabitol and erythritol was the highest, 


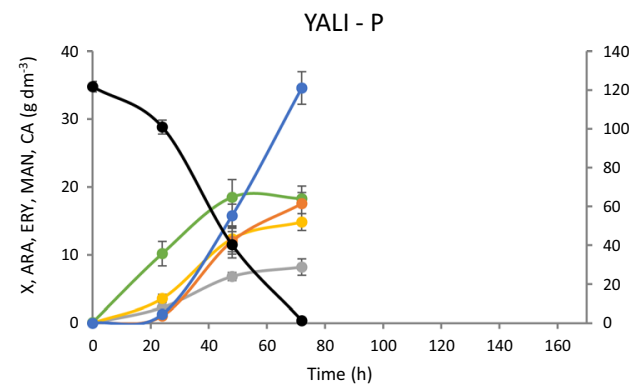

YAAL - $P$

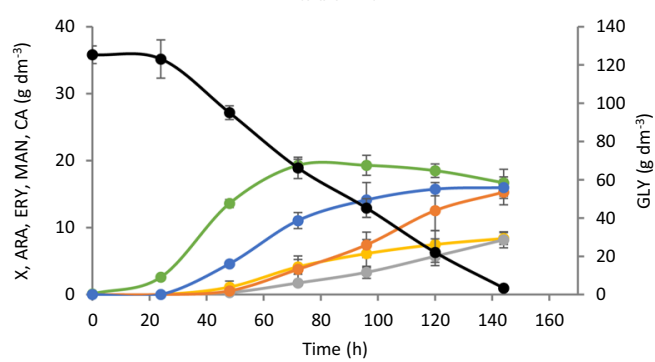

YABU - $P$
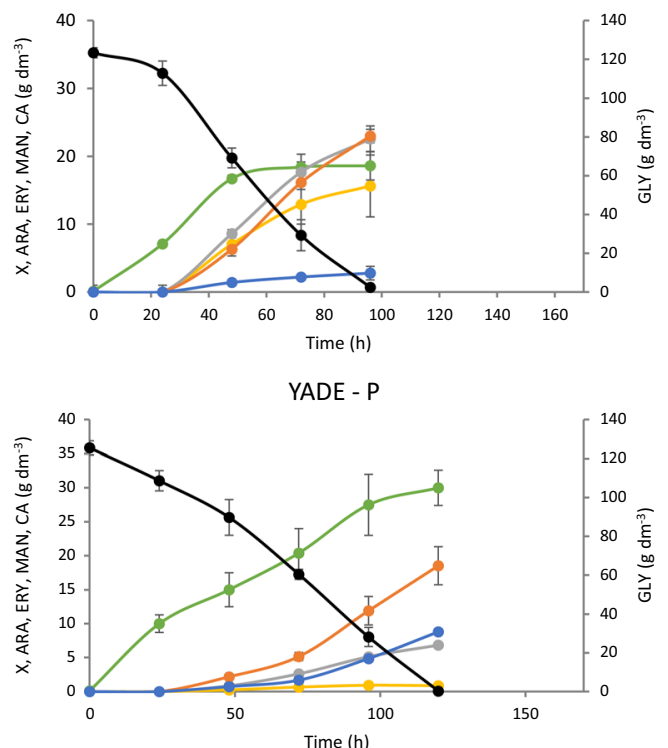

Fig. 4 Kinetics of growth

glycerol consumption (-) as well as arabitol triplicate

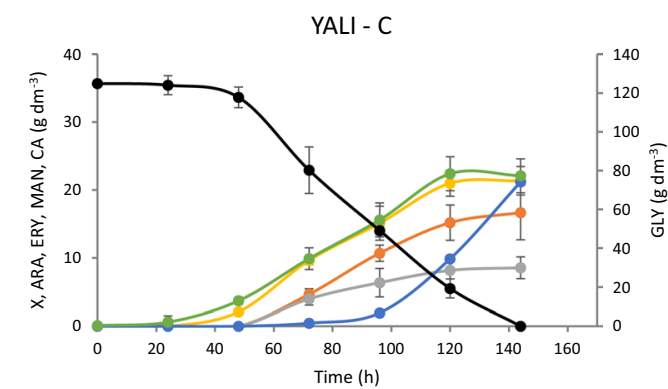

YAAL - C

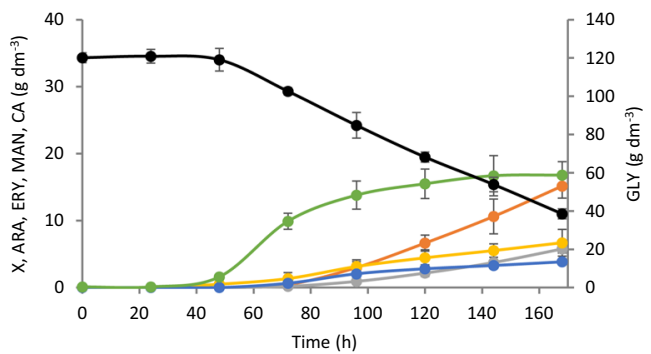

YABU - C

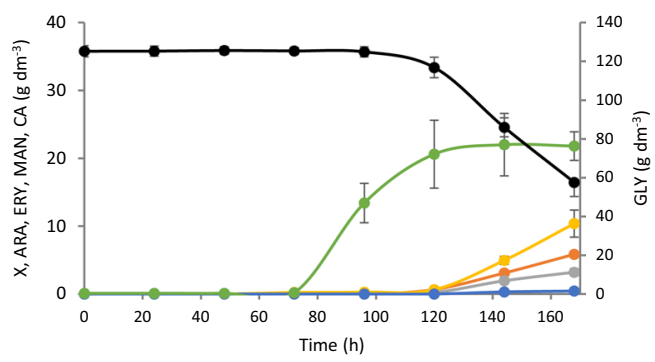

YADE - C

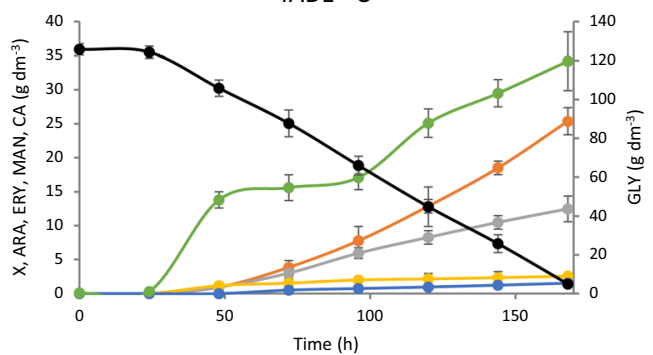

), erythritol

, mannitol

(O) and citric acid

secretion by Yarrowia ments were performed in were YADI $\left(79.46 \mathrm{~g} \mathrm{dm}^{-3}\right)$ and YAOS $\left(76.78 \mathrm{~g} \mathrm{dm}^{-3}\right)$. Interestingly, the same species growing in medium with pure substrate secreted 10 or more $\mathrm{g} \mathrm{dm}^{-3}$ less polyols (Additional file 1: Table S1). Among the other species, YAHO also deserves attention due to the high concentration of polyols produced. This species secreted $72.62 \mathrm{~g} \mathrm{dm}^{-3}$ growing on pure glycerol and $63.84 \mathrm{~g} \mathrm{dm}^{-3}$ from the crude substrate. These strains produced large amounts of polyols on both substrates, whereas the remaining species were characterized by high production of polyols on one substrate only. YADI, YAOS and YAHO also showed the highest yield of polyol biosynthesis, which exceeded $0.6 \mathrm{~g} \mathrm{~g}^{-1}$ (Fig. 5). Among all analyzed species, OLHI was found to be the weakest polyol producer. It secreted not more than $20 \mathrm{~g} \mathrm{dm}^{-3}$ of polyols regardless of the used glycerol.

Each of the analyzed yeast species was characterized by a different profile of polyols produced. Differences 


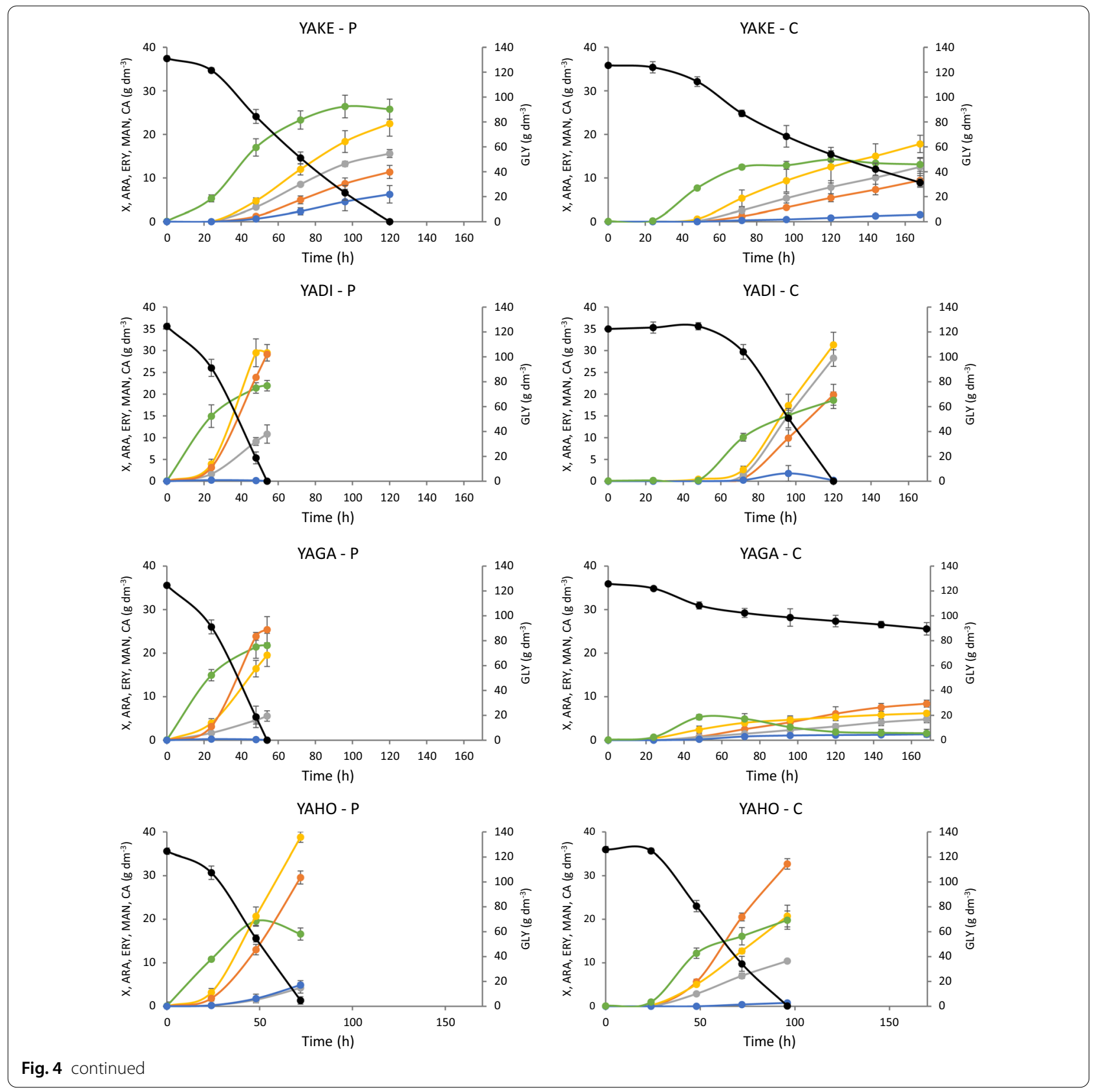

in the amount of each individual polyol produced were also observed depending on the substrate used for the same species (Fig. 5, Additional file 1: Table S1). The best erythritol yield was noted for YAHO $\left(0.33 \mathrm{~g} \mathrm{~g}^{-1}\right)$ when crude glycerol was used as a carbon source. However, the highest productivity of the same polyol was reached by YADI $\left(0.54 \mathrm{~g} \mathrm{dm}^{-3} \mathrm{~h}^{-1}\right)$ growing on the same substrate. The best arabitol producer from crude glycerol was YAOS $\left(0.25 \mathrm{~g} \mathrm{~g}^{-1}\right)$, whereas the same polyol was secreted much better by YABU $\left(0.2 \mathrm{~g} \mathrm{~g}^{-1}\right)$ when pure glycerol was used. In general, most of the analyzed species secreted less arabitol when pure glycerol was applied. In turn, mannitol secretion was the highest for YAHO, YAYA, YAGA and YAOS and ranged from 0.22 to $0.26 \mathrm{~g} \mathrm{~g}^{-1}$ (Fig. 5, Additional file 1: Table S1), whereas it should be noted that YAGA grew poorly and its final mannitol concentration reached only $8.4 \mathrm{~g} \mathrm{dm}^{-3}$. For all the studied species, the only byproduct produced during the fermentation was citric acid. Interestingly, the concentration of citric acid was higher when pure glycerol was used as a 

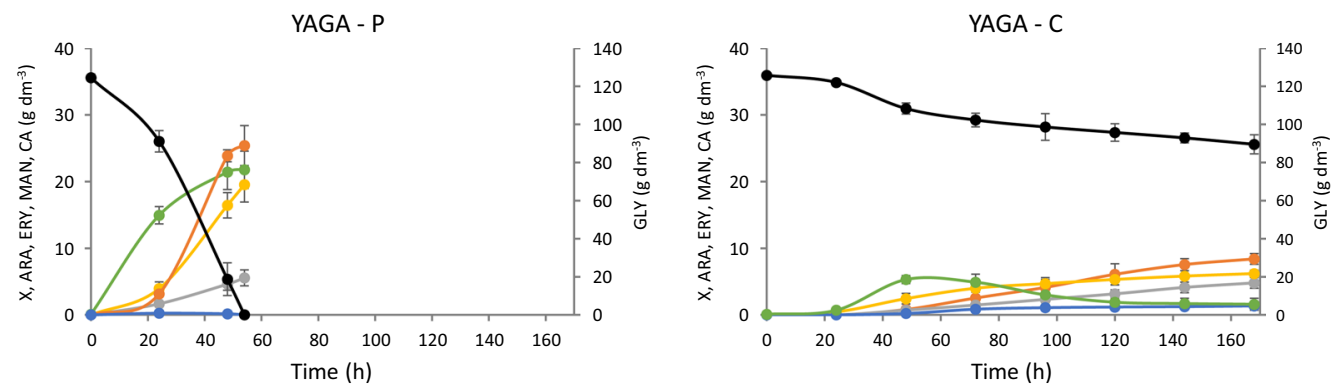

YAHO - P
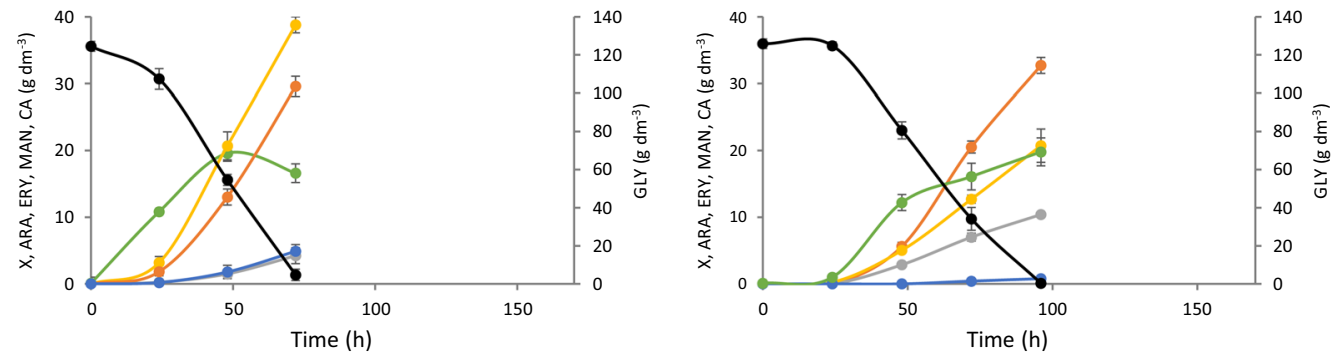

YAPO - P

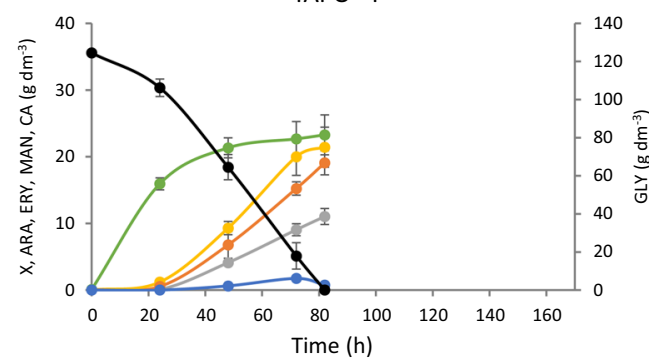

YAPO - C

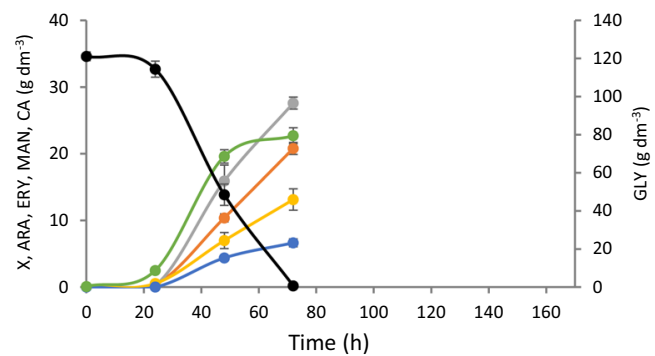

YAYA - P

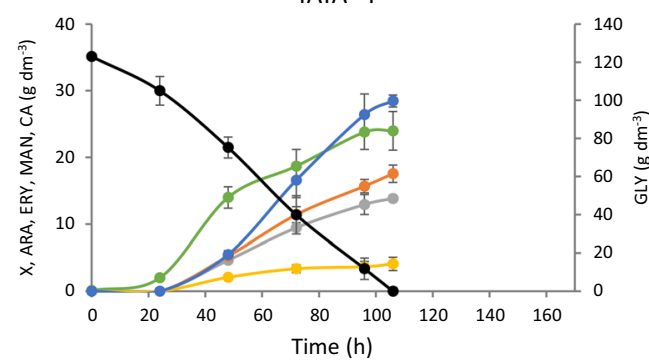

YAYA - C

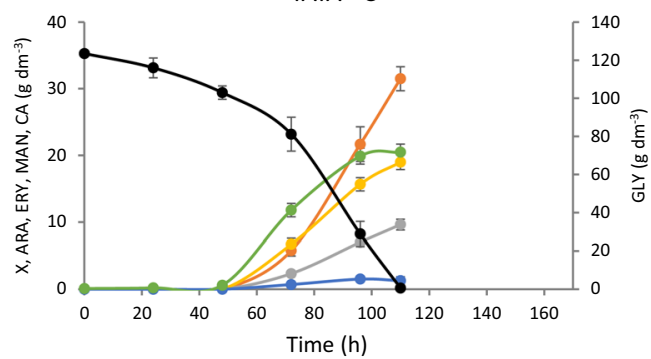

OLHI - P

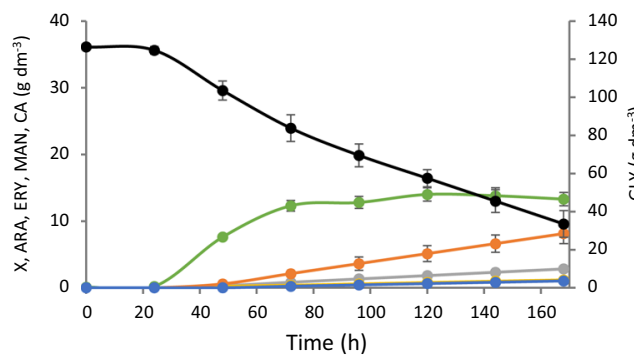

OLHI - C

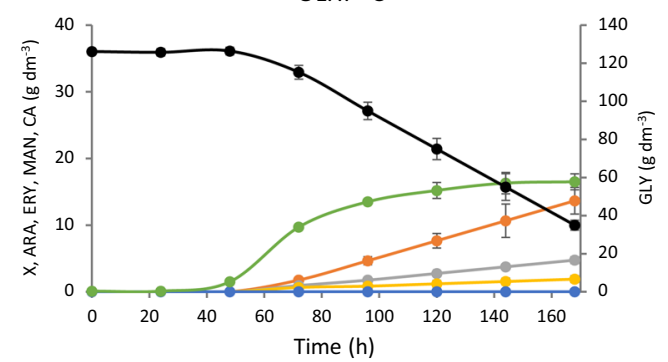

Fig. 4 continued 

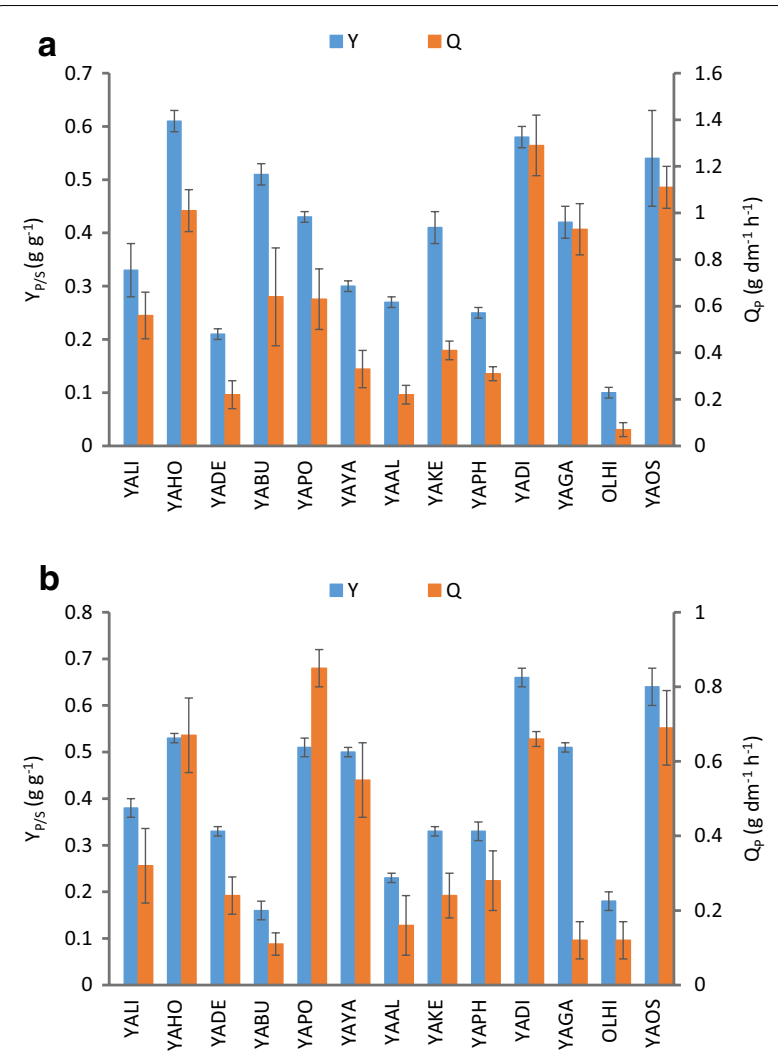

Fig. 5 Yield and productivity of total polyol (erythritol, arabitol and mannitol) biosynthesis by the yeast belonging to Yarrowia clade growing on pure (a) and crude glycerol (b) from biodiesel industry in bioreactor cultures

carbon source and a significant amount of it was secreted only for YALI, YAAL and YAYA (Fig. 4). Other species either produced less than $10 \mathrm{~g} \mathrm{dm}^{-3}$ of this compound or no citric acid secretion was observed.

Based on the available literature data, the best known and the most efficient polyol-producing species is $Y$. lipolytica [47]. A genetically engineered strain of Y. lipolytica overexpressing the SUC2 gene from S. cerevisiae (invertase) together with the native GUT1 gene (glycerol kinase) produced polyols with the yield of $0.67 \mathrm{~g} \mathrm{~g}^{-1}$ from sucrose and glycerol [47]. Similar results were obtained in the current study for YADI growing on crude glycerol from the biodiesel industry $\left(0.66 \mathrm{~g} \mathrm{~g}^{-1}\right)$. Furthermore, most of the available information about polyol production, especially erythritol biosynthesis, comes from studies on Y. lipolytica or C. magnoliae [32]. The high erythritol yield, described in the literature, obtained for different $Y$. lipolytica strains ranged from 0.5 to $0.6 \mathrm{~g} \mathrm{~g}^{-1}$ in batch or fed-batch cultures [4, 15, 50, 61]. Another erythritol producer, C. magnoliae, showed lower erythritol yield noted even for fed-batch cultures $\left(\sim 0.4 \mathrm{~g} \mathrm{~g}^{-1}\right)$ $[24,51]$. The same species is also able to produce

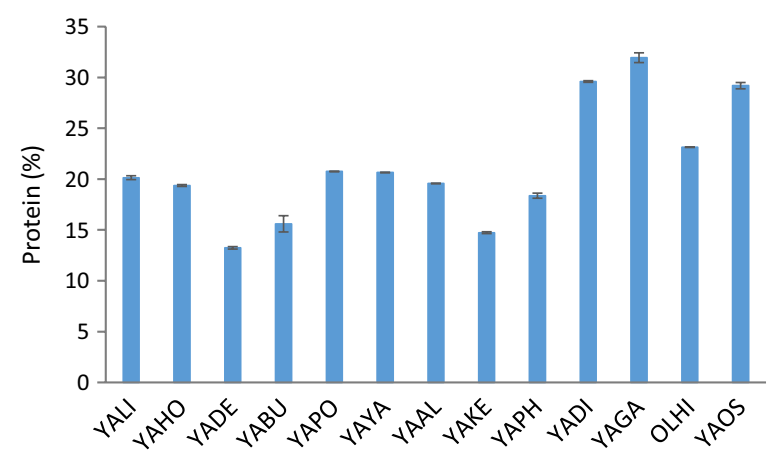

Fig. 6 Protein content of the yeast biomass of Yarrowia clade species growing on crude glycerol from biodiesel industry in bioreactor cultures

mannitol. In shake flask culture C. magnoliae secreted $67 \mathrm{~g} \mathrm{dm}^{-3}$ of mannitol from fructose $\left(\sim 0.45 \mathrm{~g} \mathrm{~g}^{-1}\right.$; [56]). Although microbiological production of mannitol is not as popular as erythritol, it is known that apart from $C$. magnoliae also Candida zeylanoides, Torulopsis mannitofaciens and Torulopsis versalitis are able to produce this compound [13, 40,56]. Even less popular is the microbiological production of arabitol. Good arabitol producers are the yeasts Debaryomyces hansenii and Candida parapsilosis, which secretes $0.51-0.54 \mathrm{~g} \mathrm{~g}^{-1}$ of this compound $[25,30]$. The best arabitol producers in the current study, YADI and YAOS, yielded $0.24-0.25 \mathrm{~g} \mathrm{~g}^{-1}$ of this polyol. All polyols produced by selected Yarrowia clade species were produced in quite high yields, especially from the crude glycerol from the biodiesel industry. This is a very good starting point for optimization of medium composition and culture parameters as well as for genetic engineering of the metabolic pathways in this species. So far, there are no available genetic tools for that yeast; however, developing efficient modification methods will most certainly allow further enhanced biosynthesis of these compounds by Yarrowia clade species.

\section{Yarrowia clade yeast as a potential SCP and SCO producing microorganism}

The composition of Yarrowia clade yeast, obtained after cultivation on crude glycerol from the biodiesel industry, as protein and lipid content as well as amino acid composition, was analyzed. All results are summarized in Figs. 6 and 7 and in Additional file 2: Table S2. The amount of protein in the yeast biomass of clade members has never been studied so far; however, it represents very valuable knowledge, especially in terms of considering these species as safe for industrial use (GRAS status). The biomass of Yarrowia clade species differed remarkably in the protein content-from 13.2 


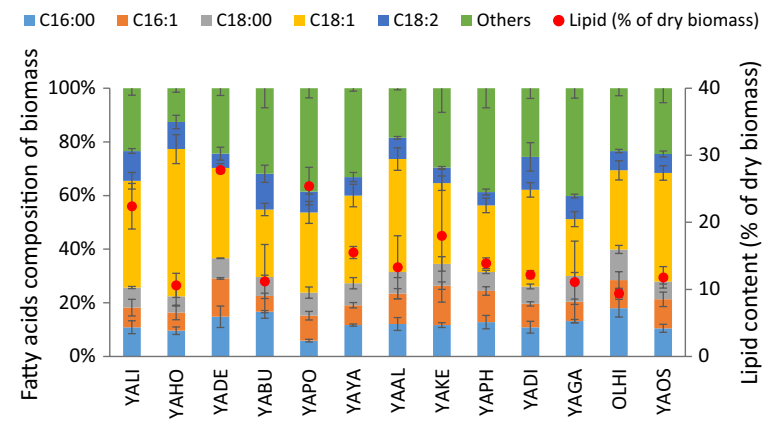

Fig. 7 Lipid content (\% of dry biomass) and fatty acid composition of the yeast biomass of Yarrowia clade species growing on crude glycerol in bioreactor cultures

to $31.9 \%$ for YADE and YAGA, respectively (Fig. 6). Similarly to polyol production, protein content can be compared to studies producing fodder yeast using $Y$. lipolytica. Juszczyk et al. [19] growing the Y. lipolytica S11 strain in medium with pure glycerol obtained very high protein content (50.1\%). In the current study, the protein content was much lower and reached only 9.4\% for the YALI strain A101 (Fig. 6). The same strain cultured in medium supplemented with lipids and selenium produced biomass with $56.4 \%$ protein [38]. Nonetheless, despite the large amount of nitrogen in the polyol production medium, it was not an optimal medium for biomass production. Due to that, the benefit here is the use of the produced biomass as a byproduct from polyol production and its utilization for fodder yeast manufacturing. To increase the protein content in the biomass of Yarrowia clade species more studies should be performed focused on sufficient supply of inorganic and organic sources of nitrogen.

The biomass was also further analyzed for its amino acid composition (Additional file 2: Table S2). In the reference protein (the amino acid composition of protein of whole egg), isoleucine, leucine, lysine, methionine/ cysteine, phenylalanine/tyrosine, threonine, tryptophan and valine are present $[17,62]$. The composition of proteins produced by Yarrowia clade species is represented by all the essential amino acids (except tryptophan, which was not analyzed in our study) in a reasonable concentration (Additional file 2: Table S2). Moreover, the composition of biomass of Yarrowia clade species was rich in aspartic and glutamic acids, alanine and lysine and poor in serine, methionine and cysteine. The composition of $Y$. lipolytica proteins obtained in the current study was comparable to the previously reported amino acid composition of this species in different industrial processes $[18,35,47]$. Furthermore, similar composition of proteins was noted for Saccharomyces cerevisiae or Candida utilis, which have already been applied for the production of feed [1].

To further explore the nutritional value of Yarrowia clade biomass, lipid content and fatty acid composition were determined (Fig. 7). The highest lipid content was noted in the biomass of YADE, YAPO and YALI and reached more than $22 \%$. It used to be the case that yeasts accumulating lipids in more than $20 \%$ of their biomass were considered as oleaginous [3]. It has already been verified that some of the Yarrowia clade members are able to accumulate a large amount of lipids inside the cells in both pathways, ex novo-the best species being YAHI [36] - and de novo-the best being YAPH [45]. Apart from the substrate used, one of the key parameters for lipid biosynthesis is the carbon to nitrogen ratio $[6,7,42]$. In general, efficient SCO production requires on one hand to maximize cell growth and, on the other hand nitrogen limitation, while avoiding its starvation [44]. Lipid production by $Y$. lipolytica strains is well documented in the literature $[5,6,31,41,46]$ and the most abundant fatty acids occurring in its lipids are: oleic acid (C18:1), palmitic acid (C16:0), stearic acid (C18:0), and palmitoleic acid (C16:1). In our study, three species showed more than 20\% lipid presence in the biomassYALI, YADE and YAPO (Fig. 7). In all cases, the dominant fatty acid was C18:1; however, YABU, YAPO, YAPH and YAGA produced very large amounts of other fatty acids in their pool of lipids. It is important to mention here that a large amount of lipids produced by cells in a process of polyol production is another benefit for using the residual biomass for feed manufacturing, especially using non-engineered strains.

\section{Cluster analysis of polyol, protein and lipid production within Yarrowia clade members}

Results obtained during polyol production using crude glycerol from biodiesel production as a carbon source were subject to cluster analysis (Fig. 8). "Polyols", "Protein" and "Lipid" were taken as variables and Ward's hierarchical agglomerative clustering method, grouping statistical data into so-called clusters having minimal internal diversity, was applied. Figure 8 presents cluster analysis in two systems of variables, "Polyols" vs. "Protein" (Fig. 8a) and "Polyols" vs. "Lipid" (Fig. 8b). Six clusters were obtained. Taking into account polyols and proteins, YADI and YAOS turned out to be very attractive species for further research (Fig. 8a). An attractive species, when polyols and lipids were taken into account, turned out to be YAPO (Fig. 8b). In both cases, YAAL, YABU and OLHI were the weakest species (Fig. 8). 

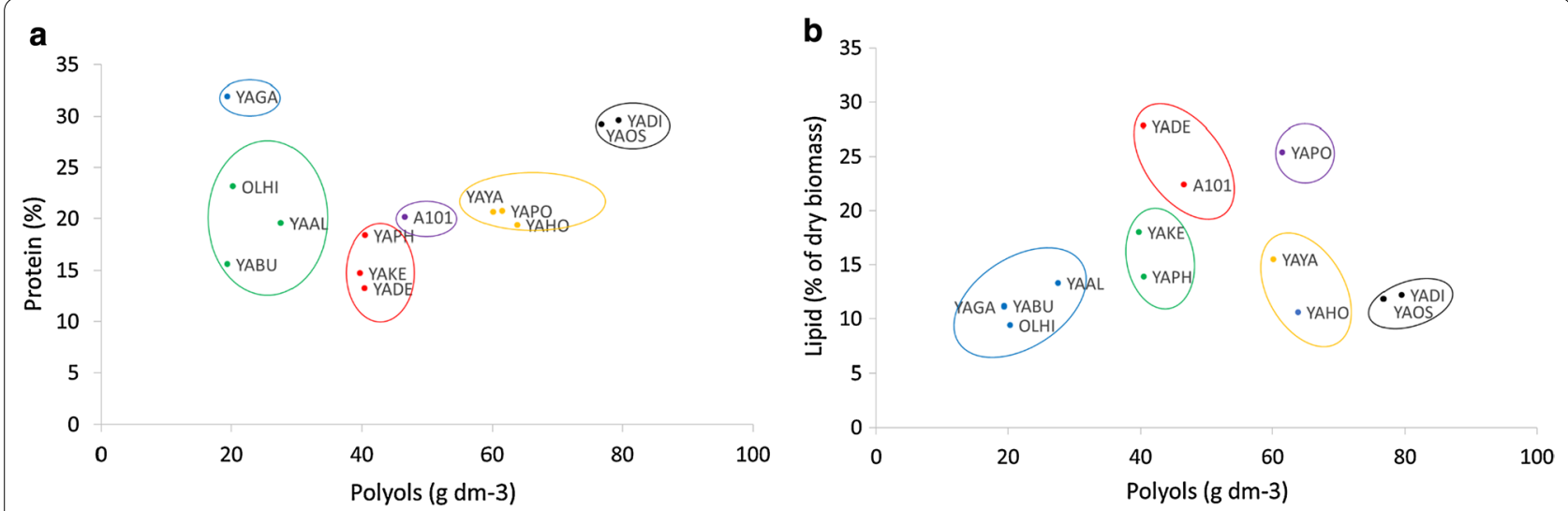

Fig. 8 Cluster analysis of: a protein content and polyol concentration, as well as $\mathbf{b}$ lipid content and polyol concentrations for Yarrowia clade yeast growing on crude glycerol-based medium during bioreactor cultures

\section{Value-added chemicals produced using crude glycerol from soap production}

Based on the results from the clustering analysis, YADI and YAOS were chosen for analysis of polyol production using crude glycerol from soap production. Both strains were cultured in bioreactors under the same conditions as for the cultures with crude glycerol from the biodiesel industry. The culture of YAOS was $10 \mathrm{~h}$ shorter than the one of YADI; however, both species produced similar amount of biomass - around $20 \mathrm{~g} \mathrm{dm}^{-3}$ (Fig. 9). The same species cultured under the same conditions on crude glycerol from biodiesel production produced a slightly smaller amount of biomass (Fig. 4). However, higher biomass production resulted in a lower concentration of polyols produced (Table 2) compared to culture biodiesel derived glycerol (Fig. 5). Both species produced around $60 \mathrm{~g} \mathrm{dm}^{-3}$ of polyols with a yield reaching $0.50-0.52 \mathrm{~g} \mathrm{~g}^{-1}$ with mannitol being predominant. Both species showed similar protein and lipid content. Crude glycerol from soap production changed these parameters. The protein content was lower and the concentration of lipids was higher, compared to the biomass obtained from crude glycerol from biodiesel production (Table 2, Fig. 6). The crucial enzymes (glycerol kinase, glycerol-3-phosphate dehydrogenase, transketolase and erythrose reductase) from the erythritol biosynthesis pathway were examined. All investigated enzymes were active during the whole culture. Glycerol kinase showed the highest activity after $24 \mathrm{~h}$ of culture for YAOS and it decreased at the stationary phase, except for YADI, where the activity of glycerol kinase remained almost at the same level (Additional file 3: Table S3). The erythrose reductase is so far considered as a determining step in the production of erythritol. In the current study the highest activity of erythrose reductase $\left(0.323 \mathrm{U} \mathrm{mg}^{-1}\right)$ during the growth phase was reported for the YADI strain (Additional file 3: Table S3). The differences in polyols production between the same strains growing on different glycerols, especially higher erythritol concentration using raw glycerol, may be caused by changes in the concentration of $\mathrm{Fe}^{2+}$ and $\mathrm{Cu}^{2+}$
YADI

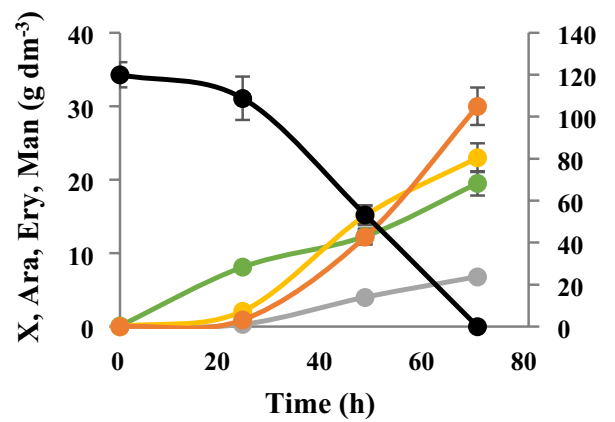

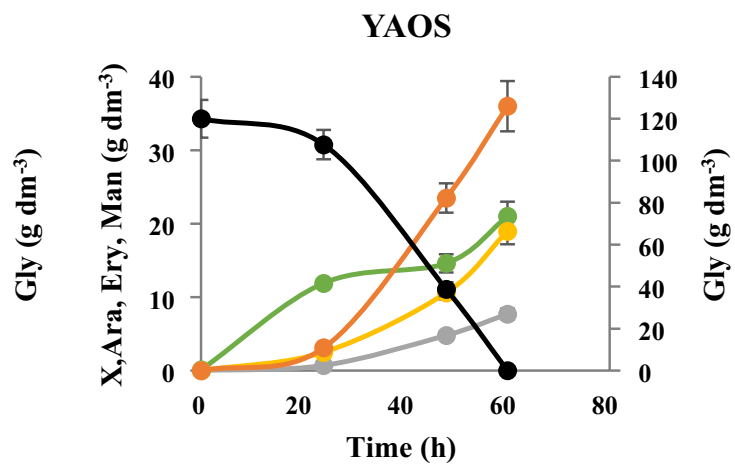

Time (h)

Fig. 9 Kinetics of growth $(\mathbf{O})$, glycerol consumption $(\mathbf{O})$ as well as arabitol (0) C. oslonensis (YAOS) during bioreactor cultures with crude glycerol from soap industry. All experiments were performed in triplicate 


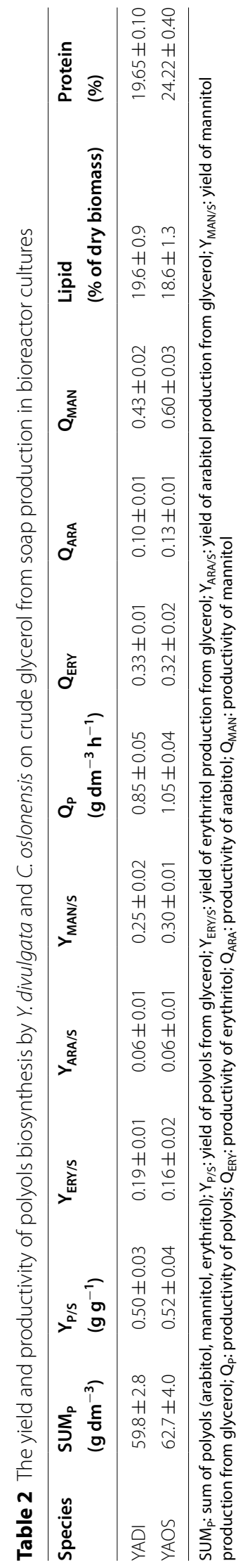


(Table 1). During erythritol biosynthesis by $C$. magnoliae, the addition of $\mathrm{Zn}^{2+}, \mathrm{Fe}^{2+}$, and $\mathrm{Ca}^{2+}$ resulted in a slight increase of erythritol concentration, while supplementation with $\mathrm{Cu}^{2+}$ and $\mathrm{Mn}^{2+}$ inhibited erythritol formation [54]. In the work of Tomaszewska et al. [61], no inhibitory effect of the divalent copper, iron, manganese, and zinc ions on the production of erythritol from glycerol by Y. lipolytica was observed. Savergave et al. [54], reported, that copper ions caused a reduction of arabitol and mannitol secretion, whereas manganese, iron, and zinc ions resulted in increased amounts of these components in comparison to erythritol.

\section{Conclusions}

Contemporary biotechnology focuses on many problems related to the functioning of developed societies. Many of the aforementioned problems are related to health, especially with the spiraling numbers of people suffering from civilization diseases, such as obesity or diabetes. An increased supply of sucrose has a particularly noticeable negative effect on health. In recent years, polyols have gained particular attention as table sugar substitutes. They are particularly desirable due to their low calorific value and the possibility of their production using microorganisms from renewable waste substrates.

In the current study, the already known potential of the yeast belonging to the Yarrowia clade for polyol production was further proved using crude glycerol obtained from the biodiesel and soap industries. Yarrowia divulgata and Candida oslonensis turned out to be particularly interesting species, as they produced the largest amount of polyols using all tested glycerol types. Furthermore, both species also produced a significant amount of biomass, which is an interesting by-product from the polyol production process. The obtained biomass was characterized by quite large amounts of proteins and lipids, which can be an attractive substrate for the production of fodder yeast. The amino acid composition of the proteins contained in the biomass contains all the necessary exogenous amino acids. Both the use of waste glycerol for the production of polyols and utilization of the biomass obtained after the process for the production of feed are part of the development of modern waste-free technologies. These results lay the foundation for future advances in polyol biosynthesis using different renewable raw materials by the means of genetic engineering and process optimization.

\section{Methods}

\section{Strains}

In this study the following strains belonging to the Yarrowia clade were used: OLHI-Candida hispaniensis CBS9996, YAAL-Candida alimentaria CBS10151,
YABU-Yarrowia bubula CBS12934, YADE-Yarrowia deformans CBS2071, YADI-Yarrowia divulgata CBS11013, YAGA-Candida galli CBS9722, YAHOCandida hollandica CBS4855, YALI-Yarrowia lipolytica A-101, YAOS-Candida oslonensis CBS10146, YAPHYarrowia phangngaensis, CBS10407, YAPO-Yarrowia porcina CBS12932, YAYA-Yarrowia yakushimensis CBS10253 and YAKE-Yarrowia keelungensis CBS11062. The strains were commercially purchased from Westerdijk Fungal Biodiversity Institute, Royal Netherlands Academy of Arts and Sciences (KNAW), Netherlands and were isolated from various biotic and abiotic environments. The species form the Yarrowia clade and were identified using a vast number of techniques such as sequence analyses of the D1/D2 domain and the ITS region, PCR-mediated fingerprint analyses, DNA-DNA reassociation and mating experiments $[2,10,22,26,27$, 29,43 ]. All strains were kept at $-80{ }^{\circ} \mathrm{C}$ in $25 \%$ (v/v) glycerol solution. One day before use, cells were inoculated on YPD plates and incubated overnight at $28^{\circ} \mathrm{C}$.

\section{Substrate}

The characteristics of substrates used in the study are listed in Table 1.

\section{Medium and culture conditions}

YPD medium containing $20 \mathrm{~g} \mathrm{dm}^{-3}$ Bactopeptone (Merck, Germany), $10 \mathrm{~g} \mathrm{dm}^{-3}$ yeast extract (Merck, Germany), $20 \mathrm{~g} \mathrm{dm}^{-3}$ glucose (Merck, Germany) was used for growing the biomass before use.

\section{Microcultures}

The growth of Yarrowia clade species was tested in the Microplate Reader, BioTek Instruments, Inc. (Winooski, Vermont, USA) in YNB medium with $5 \mathrm{~g} \mathrm{dm}^{-3}$ of $\mathrm{NH}_{4} \mathrm{Cl}$ (Yeast Nitrogen Base, Sigma) and 2\% (w/v) of glycerol (GLY1, GLY2, GLY3). The precultures were grown for $24 \mathrm{~h}$ in YPD medium at $28^{\circ} \mathrm{C}, 180 \mathrm{rpm}$, followed by centrifugation. Cells were washed twice with sterile distilled water and the optical density $\left(\mathrm{OD}_{600}\right)$ of the inoculum was standardized to 10 . Growth profiles were analyzed in a 96-well plate containing $190 \mu \mathrm{L}$ of the medium and $10 \mu \mathrm{L}$ of the inoculum. Cells were grown for $72 \mathrm{~h}$ at $22^{\circ} \mathrm{C}$ with continuous shaking and analysis of $\mathrm{OD}_{600}$ every $15 \mathrm{~min}$. The experiments were performed in triplicate for each strain.

\section{Shake flask experiment}

The differences in polyol biosynthesis using three types of glycerol were tested using the shake flasks and the medium consisted of: carbon source (GLY1, GLY2, GLY3)-100 g; $\left(\mathrm{NH}_{4}\right)_{2} \mathrm{SO}_{4}-2.7$ g; $\mathrm{KH}_{2} \mathrm{PO}_{4}-0.2$ g; $\mathrm{MgSO}_{4} 7 \mathrm{H}_{2} \mathrm{O}-1 \mathrm{~g}$; yeast extract- $1.6 \mathrm{~g}$; in $1 \mathrm{dm}^{3}$ of tap 
water [48]. The precultures were grown in YP medium containing the same carbon source $(2 \%)$ as the main culture (GLY1, GLY2, GLY3) for $48 \mathrm{~h}$ in a $250 \mathrm{~cm}^{3}$ flask on a rotary shaker at $28{ }^{\circ} \mathrm{C}$ and $140 \mathrm{rpm}$. Precultures were harvested at $\mathrm{OD}_{600}$ between 5 and 7. Flasks containing $50 \mathrm{~cm}^{3}$ of the main polyol production medium were inoculated to an initial $\mathrm{OD}_{600}$ of 0.25 and cultivated at $28{ }^{\circ} \mathrm{C}$ in $250 \mathrm{~cm}^{3}$ Erlenmeyer flasks at $200 \mathrm{rpm}$ for 6 days. The experiment was performed in three biological replicates for each strain.

\section{Bioreactor studies}

Mannitol, arabitol and erythritol production was also analyzed in bioreactor cultures in medium containing: carbon source (GLY1, GLY2)-100 g; $\left(\mathrm{NH}_{4}\right)_{2} \mathrm{SO}_{4}-2.7 \mathrm{~g}$; $\mathrm{KH}_{2} \mathrm{PO}_{4}-0.2 \mathrm{~g} ; \mathrm{MgSO}_{4} \cdot 7 \mathrm{H}_{2} \mathrm{O}-1$ g; yeast extract- $1.6 \mathrm{~g}$; in $1 \mathrm{dm}^{3}$ of tap water. The precultures were grown in $100 \mathrm{~cm}^{3}$ YP medium with $2 \%$ of the corresponding glycerol for $72 \mathrm{~h}$ in $300 \mathrm{~cm}^{3}$ flasks on a rotary shaker at $28{ }^{\circ} \mathrm{C}$ and $140 \mathrm{rpm}$. Precultures were harvested, the biomass was washed twice with sterile distilled water and the initial optical density $\left(\mathrm{OD}_{600}\right)$ in the bioreactor was adjusted to 0.5 . All bioreactor cultures were performed in a $5 \mathrm{dm}^{3}$ stirred-tank reactor (BIOSTATB-PLUS, Sartorius, Germany) with the working volume of $2.0 \mathrm{dm}^{3}$ at $28^{\circ} \mathrm{C}\left(22^{\circ} \mathrm{C}\right.$ for YAAL and YAKE). Aeration and stirring rates were set at $0.8 \mathrm{vvm}$ and $800 \mathrm{~min}^{-1}$, respectively. $\mathrm{pH} 3$ was maintained automatically by additions of $20 \%(\mathrm{w} / \mathrm{v}) \mathrm{NaOH}$ solution. All cultures were run until complete exhaustion of the carbon source. A bioreactor with the appropriate medium was sterilized in an autoclave at $121{ }^{\circ} \mathrm{C}$ for $20 \mathrm{~min}$. All cultures were conducted in three biological replicates and standard deviations were calculated.

\section{Analytical methods}

During shake flask experiment, $10 \mathrm{~cm}^{3}$ of cultures was collected at the end of the process. Samples $\left(10 \mathrm{~cm}^{3}\right)$ from bioreactor cultures were taken every $24 \mathrm{~h}$. The samples were centrifuged ( $5 \mathrm{~min}, 5000 \mathrm{rpm}$ ). The biomass was washed with distilled water and filtered on $0.45 \mu \mathrm{m}$ pore size membranes. The biomass was determined gravimetrically after drying at $105^{\circ} \mathrm{C}$ and expressed in $\mathrm{g} \mathrm{dm}^{-3}$. The concentrations of glycerol, erythritol, mannitol, arabitol, citric acid and $\alpha$-ketoglutaric acid were measured in the supernatants using high performance liquid chromatography (Dionex-Thermo Fisher Scientific, UK) with a HyperRez Carbohydrate H+ column (Thermo Scientific, Waltham, MA) coupled to a UV $(\mathrm{k}=210 \mathrm{~nm})$ and a refractive index (RI) detector (Shodex, Ogimachi, Japan). The column was eluted with $25 \mathrm{mM}$ trifluoroacetic acetic acid with a rate of $0.6 \mathrm{~cm}^{3} \mathrm{~min}^{-1}$ at $65^{\circ} \mathrm{C}$.

The residual biomass after the bioreactor processes was subjected to lipid, protein and amino acids composition analysis. The amino acid composition of samples was determined by ion-exchange chromatography after $23 \mathrm{~h}$ of hydrolysis with $6 \mathrm{~N} \mathrm{HCl}$ at $110{ }^{\circ} \mathrm{C}$. After cooling, filtering and washing, the hydrolyzed sample was evaporated in a vacuum evaporator at a temperature below $50{ }^{\circ} \mathrm{C}$. The dry residue was dissolved in a buffer of $\mathrm{pH}$ 2.2. The prepared sample was analyzed using the ninhydrin method [55, 57]. The $\mathrm{pH} 2.6,3.0,4.25$, and 7.9 buffers were applied. The ninhydrin solution was buffered at $\mathrm{pH}$ 5.5. The hydrolyzed amino acids were determined using an AAA-400 analyzer (INGOS, Prague, Czech Republic). A photometric detector was used, working at two wavelengths, $440 \mathrm{~nm}$ and $570 \mathrm{~nm}$. A column of $350 \times 3.7 \mathrm{~mm}$, packed with ion exchanger Ostion LG ANB (INGOS), was used. Column temperature was kept at $60-74{ }^{\circ} \mathrm{C}$ and detector temperature at $121{ }^{\circ} \mathrm{C}$. The calculations were carried out relative to an external standard. No analysis of tryptophan was carried out.

Lipids determination was conducted by the two-step direct transesterification method. $1 \mathrm{mg}$ of biomass was collected, centrifuged for $2 \mathrm{~min}$ at $8000 \mathrm{rpm}$ and the supernatant was discarded. Next, $100 \mu \mathrm{L}$ of C17:0 internal standard (Sigma-Aldrich, St. Louis, MO, USA) was added to the samples. After addition of $500 \mu \mathrm{L}$ of $0.5 \mathrm{M}$ sodium methoxide, the samples were vortexed for $60 \mathrm{~min}$ at room temperature. Following incubation, $40 \mu \mathrm{L}$ of anhydrous $\mathrm{H}_{2} \mathrm{SO}_{4}$ and $1 \mathrm{~mL}$ of hexane were added and left overnight at room temperature. After centrifugation at $8000 \mathrm{rpm}$ for $1 \mathrm{~min}$ the upper hexane layer containing fatty acid methyl esters (FAMEs) was collected and analyzed by a GC-MS instrument (Shimadzu, Kyoto, Japan) equipped with a Zebron ZB-FAME capillary column $(30 \mathrm{~m} \times 0.25 \mathrm{~mm} \times 0.20 \mu \mathrm{m})$. The samples $(1 \mu \mathrm{L}$ at $250{ }^{\circ} \mathrm{C}$ ) were injected in splitless mode using helium $\left(1 \mathrm{~mL} \mathrm{~min}^{-1}\right)$. Identification of fatty acids was carried out by comparison of retention times with reference compounds (Supelco 37 Component FAME Mix, Sigma-Aldrich).

\section{Enzymatic assays}

The key enzyme activities were measured in the growth phase (after $24 \mathrm{~h}$ of culture) and at the end of the production phase $(96 \mathrm{~h})$ for YAOS and YADI strains, according to Tomaszewska et al. [63]. Activities of the enzymes important for erythritol biosynthesis [glycerol kinase-GK, (EC 2.7.1.30) [20], glycerol-3-phosphate dehydrogenase-GPDH, (EC 1.1.1.8) [64], transketolase-TK, (EC 2.2.1.1) [59] and erythrose reductaseER, (EC 1.1.1.21)] were determined in the supernatants [14]. One unit (U) of the enzyme activity was defined as $1 \mu \mathrm{mol}$ of NADH/NADPH consumed or produced within $1 \mathrm{~min}(\lambda=340 \mathrm{~nm})$ at the reaction conditions. 
The enzyme activities were expressed as $\mathrm{U}$ per $\mathrm{mg}$ of protein (U mg ${ }^{-1}$ of protein) and as $U$ per $100 \mathrm{mg} \mathrm{sam-}$ ples of cell dry weight $\left(\mathrm{U} \mathrm{CDW}^{-1}\right)$. The assay for each strain was carried out in three biological replicates (bioreactor culture) and three technical replicates and standard deviations were calculated.

\section{Calculation of fermentation parameters}

The yield of sum of polyols, arabitol, erythritol and mannitol from glycerol $\left(Y_{P}, Y_{E R Y}, Y_{A R A}, Y_{M A N}\right)$, expressed in $\mathrm{g} \mathrm{g}^{-1}$, was calculated using Eq. (1) [52]:

$$
Y_{P}=\frac{P}{S}
$$

The yield of polyols, arabitol, erythritol, mannitol production from biomass $\left(\mathrm{Y}_{\mathrm{X}}\right)$, expressed in $\mathrm{g} \mathrm{g}^{-1}$, was calculated using Eq. (2) [52]:

$$
Y_{X}=\frac{P}{X} .
$$

The productivity of total polyols, arabitol, erythritol and mannitol $\left(\mathrm{Q}_{\mathrm{P}}, \mathrm{Q}_{\mathrm{ARA}}, \mathrm{Q}_{\mathrm{ERY}}, \mathrm{Q}_{\mathrm{MAN}}\right)$, expressed in $\mathrm{g} \mathrm{dm}^{-3} \mathrm{~h}^{-1}$, was calculated using Eq. (3) [52]:

$$
Q=\frac{P}{t} \text {. }
$$

In all these equations, $\mathrm{P}$ denotes total polyols, arabitol, erythritol, mannitol concentration in the culture broth at the end of the cultivations $\left(\mathrm{g} \mathrm{dm}^{-3}\right), \mathrm{S}$ indicates the total amount of glycerol consumed $\left(\mathrm{g} \mathrm{dm}^{-3}\right), \mathrm{t}$ denotes duration of the fermentation process (h), and $\mathrm{X}$ represents biomass concentration $\left(\mathrm{g} \mathrm{dm}^{-3}\right)$.

Cluster analysis (Ward's method) was used to find homologous groups among the strains when polyol and protein concentrations and polyol and lipid contents in bioreactor cultures on glycerol from the biodiesel industry were taken into account. Squared Euclidean distance was taken as a measure of proximity between strains. Results of the study were analyzed statistically with GNU Octave 4.3.0+ software using two functions. The first of them returns the Euclidean distance between any two rows in the input data. The second function produces a hierarchical clustering dendrogram using the Ward method that defines the way the distance between two clusters is computed. In this case, it is the sum of squared deviations about the group mean.

\section{Abbreviations}

OLHI: Candida hispaniensis CBS9996; YAAL: Candida alimentaria CBS10151; YABU: Yarrowia bubula CBS12934; YADE: Yarrowia deformans CBS2071; YADI: Yarrowia divulgata CBS11013; YAGA: Candida galli CBS9722; YAHO: Candida hollandica CBS4855; YALI: Yarrowia lipolytica A-101; YAOS: Candida oslonensis CBS10146; YAPH: Yarrowia phangngaensis, CBS10407; YAPO: Yarrowia porcina CBS12932; YAYA: Yarrowia yakushimensis CBS10253; YAKE: Yarrowia keelungensis CBS11062

\section{Supplementary Information}

The online version contains supplementary material available at https://doi. org/10.1186/s12934-021-01686-0.

Additional file 1: Table S1. The yield and productivity of erythritol, arabitol and mannitol biosynthesis by the yeast belonging to Yarrowia clade growing on pure and crude glycerol from biodiesel industry in bioreactor cultures.

Additional file 2: Table S2. Amino acids composition of the yeast biomass of Yarrowia clade species growing on crude glycerol from biodiesel industry in bioreactor cultures.

Additional file 3: Table S3. Comparison of enzymatic activities of key enzymes from erythritol biosynthesis pathway from glycerol by selected stains from the Yarrowia clade.

\section{Acknowledgements}

Not applicable.

\section{Authors' contributions}

MRP: designed and performed experiments, wrote and revised the manuscript, acquired the funding, JM: performed the protein and amino acid analysis; DJ: performed flask and bioreactor cultures, SK: performed flask and bioreactor experiments, KL: performed flask and bioreactor cultures, TJ: performed lipid analysis experiment, GS: performed flask and bioreactor experiments, WR: discussed the results, revised the manuscript, ZL: designed and performed experiments, helped to write and revised the manuscript, acquired the funding. All authors read and approved the final manuscript.

\section{Funding}

This research was funded by the National Science Centre, Poland grant MINIATURA 2 DEC-2692018/02/X/NZ9/00395 'Biochemical characteristics of erythritol and mannitol biosynthesis pathways in yeast from Yarrowia clade'. The article processing charge (APC) was financed under the Leading Research Groups support project from the subsidy increased for the period 2020-2025 in the amount of 2\% of the subsidy referred to in Art. 387 (3) of the Law of 20 July 2018 on Higher Education and Science, obtained in 2019.

\section{Availability of data and materials}

The datasets used and/or analyzed during the current study are available from the corresponding author on reasonable request.

\section{Declarations}

Ethics approval and consent to participate Not applicable.

\section{Consent for publication}

Not applicable.

\section{Competing interests}

The authors declare that they have no competing interests.

\section{Author details}

${ }^{1}$ Department of Biotechnology and Food Microbiology, Wroclaw University of Environmental and Life Sciences, Chełmońskiego 37, 51-630 Wroclaw, Poland. ${ }^{2}$ Department of Food Storage and Technology, Wroclaw University of Environmental and Life Sciences, Chełmońskiego 37, 51-630 Wroclaw, Poland.

Received: 10 June 2021 Accepted: 24 September 2021

Published online: 09 October 2021 


\section{References}

1. Adedayo MR, Ajiboye EA, Akintunde JK, Odaibo A. Single cell proteins: as nutritional enhancer. Adv Appl Sci Res. 2011:2:396-409.

2. Barth G, Gaillardin C. Physiology and genetics of the dimorphic fungus Yarrowia lipolytica. FEMS Microbiol Rev. 1997:19(4):219-37.

3. Beopoulos A, Cescut J, Haddouche R, Uribelarrea JL, Molina-Jouve C, Nicaud JM. Yarrowia lipolytica as a model for bio-oil production. Prog Lipid Res. 2009;48:375-87

4. Carly F, Vandermies M, Telek S, Steels S, Thomas S, Nicaud JM, Fickers P. Enhancing erythritol productivity in Yarrowia lipolytica using metabolic engineering. Metab Eng. 2017;42:19-24.

5. Chatzifragkou A, Makri A, Belka A, Bellou S, Mavrou M, Mastoridou M, Mystrioti P, Onjaro G, Aggelis G, Papanikolaou S. Biotechnological conversions of biodiesel derived waste glycerol by yeast and fungal species. Energy. 2011;36:1097-108

6. Dobrowolski A, Mituła P, Rymowicz W, Mirończuk AM. Efficient conversion of crude glycerol from various industrial wastes into single cell oil by yeast Yarrowia lipolytica. Bioresour Technol. 2016;207:237-43.

7. Dourou M, Kancelista A, Juszczyk P, Sarris D, Bellou S, Triantaphyllidou IE, Rywińska A, Papanikolaou S, Aggelis G. Bioconversion of olive mill wastewater into high-added value products. J Clean Prod. 2016;139:957-69.

8. El-Bakry M, Abraham J, Cerda A, Barrena R, Ponsa S, Gea T. From wastes to high value added products: novel aspects of SSF in the production of enzymes. Crit Rev Environ Sci Technol. 2015;45(18):1999-2042.

9. El-Baz HA, Elazzazy AM, Saleh TS, Dritsas P, Mahyoub JA, Baeshen MN, Madian HR, Alkhaled M, Aggelis G. Single cell oil (SCO)-based bioactive compounds: I-enzymatic synthesis of fatty acid amides using SCOs as acyl group donors and their biological activities. Appl Biochem Biotechnol. 2021:193:822-45.

10. Groenewald M, Smith M. The teleomorph state of Candida deformans Langeron \& Guerra and description of Yarrowia yakushimensis comb. nov. Antonievan Leeuwenhoek. 2013;103(5):1023-8.

11. Gonçalves C, Ferreira C, Gonçalves LG, Turner DL, Leandro MJ, SalemaOom M, Santos H, Gonçalves P. A new pathway for mannitol metabolism in yeasts suggests a link to the evolution of alcoholic fermentation. Front Microbiol. 2019;10:2510

12. Hapeta P, Szczepańska P, Neuvéglise C, Lazar Z. A 37-amino acid loop in the Yarrowia lipolytica hexokinase impacts its activity and affinity and modulates gene expression. Sci Rep. 2021;11:6412.

13. Hattori K, Suzuki T. Large scale production of erythritol and its conversion to d-mannitol production by n-alkane-grown Candida zeylanoides. Agric Biol Chem. 1974:38:1203-8.

14. JanekT, Dobrowolski A, Biegalska A, Mirończuk AM. Characterization of erythrose reductase from Yarrowia lipolytica and its influence on erythritol synthesis. Microb Cell Fact. 2017;16:118.

15. Jeya M, Lee KM, Tiwari MK, Kim JS, Gunasekaran P, Kim SY, Kim IW, Lee JK. Isolation of a novelhigh erythritol-producing Pseudozyma tsukubaensis and scale-up of erythritol fermentation to industrial level. Appl Microbiol Biotechnol. 2009:83:225-31.

16. Johnson DT, Taconi KA. The glycerin glut: options for value-added conversion of crude glycerol resulting from biodiesel production. Environ Prog. 2007;26(4):338-48.

17. Juszczyk P, Rymowicz W. Characterization of microbial biomass production from glycerin waste by various yeast strains. In: Aggelis G, editor. Microbial conversions of raw glycerol. Nova Science Publishers: New York; 2009. p. $125-35$

18. Juszczyk P, Rymowicz W, Kita A, Rywińska A. Biomass production by Yarrowia lipolytica yeast using waste derived from the production of ethyl esters of polyunsaturated fatty acids of flaxseed oil. Ind Crops Prod. 2019:138:111590.

19. Juszczyk P, Tomaszewska L, Kita A, RymowiczW. Biomass production by novel strains of Yarrowia lipolytica using raw glycerol, derived from biodiesel production. Bioresour Technol. 2013;137:124-31.

20. Kamzolova SV, Finogenova TV, Morgunov IG. Microbiological production of citric and isocitric acisd from sunflower oil. Food Technol Biotechnol. 2008:46:51-9.

21. Khan A, Bhide A, Gadre R. Mannitol production from glycerol by resting cells of Candida magnoliae. Bioresour Technol. 2009;100(20):4911-3.

22. Knutsen AK, Robert V, Poot GA, Epping W, Figge M, Holst-Jensen A, Skaar I, Smith M. Polyphasic re-examination of Yarrowia lipolytica strains and the description of three novel Candida species: Candida oslonensis sp. nov.,
Candida alimentaria sp. nov. and Candida hollandica sp. nov. Int J Syst Evol Microbiol. 2007;57:2426-35.

23. Koganti S, Kuo TM, Kurtzman CP, Smith N, Ju LK. Production of arabitol from glycerol: strain screening and study of factors affecting production yield. Appl Microbiol Biotechnol. 2011;90(1):257-67.

24. Koh ES, Lee TH, Lee DY, Kim HJ, Ryu YW, Jin-Ho Seo JH. Scale-up of erythritol production by an osmophilic mutant of Candida magnoliae. Biotechnol Lett. 2003;25:2103-5.

25. Kordowska-Wiater M, Kuzdraliński A, Czernecki T, Targoński Z, Frąc M, Oszust K. The production of arabitol by a novel plant yeast isolate Candida parapsilosis 27RL-4. Appl Microbiol Biotechnol. 2017;102:641-53.

26. Kurtzman CP. New species and a new combination in the Hyphopichia and Yarrowia yeast clades. Antonie Van Leeuwenhoek. 2005;88:121-30.

27. Kurtzman CP. Yarrowia van der Walt \& von Arx (1980). In: Kurtzman CP, Fell JW, Boekhout T, editors. The Yeasts, a taxonomic study. London: Elsevier; 2011. p. 927-9.

28. Lazar Z, Liu N, Stephanopoulos G. Holistic approaches in lipid production by Yarrowia lipolytica. Crit Rev Biotechnol. 2018;38(4):620-33.

29. Limtong S, Youngmanitchai W, Kawasaki H, Seki T. Candida phangngensis sp. nov., an anamorphic yeast species in the Yarrowia clade, isolated from water in mangrove forests in Phang-Nga Province, Thailand. Int J Syst Evol Microbiol. 2008;58:515-9.

30. Loman AA, Islam SMM, Ju LK. Production of arabitol from enzymatic hydrolysate of soybean flour by Debaryomyces hansenii fermentation. Appl Microbiol Biotechnol. 2018;102(2):641-53.

31. Makri A, Fakas S, Aggelis G. Metabolic activities of biotechnological interest in Yarrowia lipolytica grown on glycerol in repeated batch cultures. Bioresour Technol. 2010;101:2351-8.

32. Martău GA, Coman V, Vodnar DC. Recent advances in the biotechnological production of erythritol and mannitol. Crit Rev Biotechnol. 2020:40(5):608-22.

33. Meng Q, Zhang T, Wei W, Mu W, Miao M. Production of mannitol from a high concentration of glucose by Candida parapsilosis SK26.001. Appl Biochem Biotechnol. 2017;181:391-406.

34. Meunchan M, Michely S, Devillers H, Nicaud JM, Marty A, Neuvéglise C. Comprehensive analysis of a yeast lipase family in the Yarrowia clade. PLOS ONE. 2015;10(11):0143096.

35. Michalik B, Biel W, Lubowicki R, Jacyno E. Chemical composition and biological value of proteins of the yeast Yarrowia lipolytica growing on industrial glycerol. Can J Anim Sci. 2014;94:99-104.

36. Michely S, Gaillardin C, Nicaud JM, Neuvéglise C. Comparative physiology of oleaginous species from the Yarrowia clade. PLoS ONE. 2013;8(5):e63356.

37. Morin N, Czerwiec Q, Nicaud JM, Neuvéglise C, Rossignol T. Transforming Candida hispaniensis, a promising oleaginous and flavogenic yeast. Yeast. 2020;37:348-55.

38. Musiał I, Juszczyk P, Rymowicz W, Kinal S. Production of selenium and chromium enriched Yarrowia lipolytica fodder yeast (in Polish). Acta Sci Pol Biotechnol. 2005:4:55-64.

39. Ochsenreither K, Glück C, Stressler T, Fischer L, Syldatk C. Production strategies and applications of microbial single cell oils. Front Microbiol. 2016;7:1539.

40. Onishi H, Suzuki T. Microbial production of D-mannitol and D-fructose from glycerol. Biotechnol Bioeng. 1970;12:913-20.

41. Papanikolaou S, Aggelis G. Lipid production by Yarrowia lipolytica growing on industrial glycerol in a single-stage continuous culture. Bioresour Technol. 2002:82:43-9.

42. Papanikolaou S, Kampisopoulou E, Blanchard F, Rondags E, Gardeli C, Koutinas AA, Chevalot I, Aggelis G. Production of secondary metabolites through glycerol fermentation under carbon-excess conditions by the yeasts Yarrowia lipolytica and Rhodosporidium toruloides. Eur J Lipid Sci Technol. 2017;119(9):1600507.

43. Péter G, Dlauchy D, Vasdinyei R, Tornai-Lehoczki J, Dek T. Candida galli sp. nov., a new yeast from poultry. Antonie Van Leeuwenhoek. 2004;86:105-10.

44. Qin L, Liu L, Zeng AP, Wei D. From low-cost substrates to single cell oils synthesized by oleaginous yeasts. Bioresour Technol. 2017;245:1507-19.

45. Quarterman J, Slininger PJ, Kurtzman CP, Thompson SR, Dien BS. A survey of yeast from the Yarrowia clade for lipid production in dilute acid pretreated lignocellulosic biomass hydrolysate. Appl Microbiol Biotechnol. 2017:101:3319-34. 
46. Rakicka M, Lazar Z, Dulermo T, Fickers P, Nicaud JM. Lipid production by the oleaginous yeast Yarrowia lipolytica using industrial by-products under different culture conditions. Biotechnol Biofuels. 2015;8:104.

47. Rakicka M, Biegalska A, Rymowicz W, Dobrowolski A, Mirończuk AM. Polyol production from waste materials by genetically modified Yarrowia lipolytica. Bioresour Technol. 2017;243:393-9.

48. Rakicka M, Kieroń A, Hapeta P, Neuvéglise C, Lazar Z. Sweet and sour potential of yeast from the Yarrowia clade. Biomass Bioenergy. 2016:92:48-54.

49. Rakicka-Pustułka M, Mirończuk AM, Celińska E, Białas W, Rymowicz W. Scale-up of the erythritol production technology_process simulation and techno-economic analysis. J Clean Prod. 2020;257:120533.

50. Rymowicz W, Rywinska A, Marcinkiewicz M. High-yield production of erythritol from raw glycerol infed-batch cultures of Yarrowia lipolytica. Biotechnol Lett. 2009;31:377-80.

51. Ryu YW, Park CY, Park JB, Kim SY, Seo JH. Optimization oferythritol production by Candida magnoliae in fed-batch culture. J Ind Microbiol Biotechnol. 2000;25:100-3.

52. Rywińska A, Marcinkiewicz M, Cibis E, Rymowicz W. Optimization of medium composition for erythritol production from glycerol by Yarrowia lipolytica using response surface methodology. Prep Biochem Biotechnol. 2015;18(45):515-29.

53. Rzechonek D, Dobrowolski A, Rymowicz W, Mirończuk AM. Recent advances in biological production of erythritol. Crit Rev Biotechnol. 2018:38(4):620-33.

54. Savergave LS, Gadre RV, Vaidya BK, Narayanan K. Strain improvement and statistical media optimization for enhanced erythritol production with minimal by-products from Candida magnoliae mutant R23. Biochem Eng J. 2011;55:92-100.

55. Simpson RJ, Neuberger MR, Lin TY. Complete amino acid analysis of proteins from a single hydrolysate. J Biol Chem. 1976;251(7):1936-40.
56. Song KH, Lee JK, Song JY, Hong SG, Baek H, Kim SY, Hyun HH. Production of mannitol by a novel strain of Candida magnoliae. Biotechnol Lett. 2002;24:9-12.

57. Spackman DH, Stein WH, Moore S. Automatic recording apparatus for use in the chromatography amino acid. Anal Chem. 1958;30(7):1190-206.

58. Spalvins K, Zihare L, Blumberga D. Single cell protein production from waste biomass: comparison of various industrial by-products. Energy Procedia. 2018;147:409-18.

59. Sugimoto S, Shiio I. Regulation of enzymes for erythrose 4-phosphate synthesis in Brevibacterium flavum. Agric Biol Chem. 1989;53:2081-7.

60. Tomaszewska L, Rywińska A, Gładkowski W. Production of erythritol and mannitol by Yarrowia lipolytica yeast in media containing glycerol. J Ind Microbiol Biotechnol. 2012;39(9):1333-43.

61. Tomaszewska L, Rymowicz W, Rywńska A. Mineral supplementation increases erythrose reductase activity in erythritol biosynthesis from glycerol by Yarrowia lipolytica. Appl Biochem Biotechnol. 2014;172:3069-78.

62. Tomaszewska L, Rywinska A, Rymowicz W. High selectivity of erythritol production from glycerol by Yarrowia lipolytica. Biomass Bioenergy. 2014;64:309-20.

63. Tomaszewska L, Rakicka M, Rymowicz W, Rywińska A. A comparative study on glycerol metabolism to erythritol and citric acid in Yarrowia lipolytica yeast cells. FEMS Yeast Res. 2014;14:966-76.

64. White HB, Kaplan NO. Purification and properties of two types of diphosphopyridine nucleotide-linked glycerol 3-phosphate dehydrogenases from chicken breast muscle and chicken liver. J Biol Chem. 1969;21:6031-9.

\section{Publisher's Note}

Springer Nature remains neutral with regard to jurisdictional claims in published maps and institutional affiliations.
Ready to submit your research? Choose BMC and benefit from:

- fast, convenient online submission

- thorough peer review by experienced researchers in your field

- rapid publication on acceptance

- support for research data, including large and complex data types

- gold Open Access which fosters wider collaboration and increased citations

- maximum visibility for your research: over $100 \mathrm{M}$ website views per year

At BMC, research is always in progress.

Learn more biomedcentral.com/submissions 